\title{
PRODUCTIVITY ASSESSMENT OF THE REAL ESTATE INDUSTRY IN CHINA: A TWO-STAGE MALMQUIST PRODUCTIVITY INDEX
}

\author{
Xiao-xiao LIU ${ }^{1,2}$, Hui-hui LIU ${ }^{1,2}$, Guo-liang YANG (1) ${ }^{1,2, *}$, Jiao-feng PAN ${ }^{1,2}$ \\ ${ }^{1}$ School of Public Policy and Management, University of Chinese Academy of Sciences, Beijing, China \\ ${ }^{2}$ Institutes of Science and Development, Chinese Academy of Sciences, Beijing, China
}

Received 18 March 2020; accepted 05 October 2020

\begin{abstract}
Considering that the real estate industry is a critical industry to promote the economy in China, it is necessary to measure the real estate performance. However, few studies about the performance evaluation of China's real estate industry have focused on the production process. To fill this gap, this paper proposes a two-stage framework to investigate the real estate productivity of 30 sample provinces on mainland China from 2008 to 2015, based on a common-weight global Malmquist productivity index (MPI). The major findings are shown as follows: (a) the real estate efficiency is low, and it is mainly caused by the inefficiency in the sales stage, not the development stage; (b) the development trend of the real estate sector in China is sensitive to the government policies, and the fluctuations of MPI are consistent with the direction of policy adjustment during the observation period; (c) as for the regional analysis of MPI, we introduce the concept of the dependence degree of the economy on the real estate industry and predict that MPI in economically underdeveloped regions may decline in the future. Finally, policy recommendations are provided for the high-quality development of China's real estate industry.
\end{abstract}

Keywords: real estate industry, China, two-stage, data envelopment analysis, common-weight global Malmquist productivity index.

\section{Introduction}

Since the reform of China's housing system in 1998, the real estate sector has become one of the most critical components of improving the national economy. According to the data released by the National Bureau of Statistics of China ${ }^{1}$, the share of value-added in the real estate sector to gross domestic product (GDP) grows from 4.0\% in 1998 to $6.5 \%$ in 2017 . However, the extensive development of the real estate sector has caused a range of negative issues, such as the severe waste of land resources (Wang et al., 2018), the imbalance of housing supply and demand (Chen et al., 2019), and the imperfection of housing system (Shi et al., 2016). Therefore, it is of considerable significance to explore how to promote the high-quality development of the real estate sector in China.

As a comprehensive industry, the real estate industry, which integrates various economic activities and takes land and buildings as business objects, is mainly engaged

\footnotetext{
1 Data source: http://www.stats.gov.cn/tjsj/ndsj/2017/indexch.htm
}

in real estate development, sales, management, and service. With the reform of China's housing system, the Chinese government gradually promotes the commercialization of the real estate industry. Therefore, commercial housing in China is the general term for houses sold or rented in the market, including residential buildings, commercial buildings (e.g., office buildings), and other buildings, which refers to houses developed by a real estate company (individual or foreign company) that rents land use rights to government agencies for 40,50 , or 70 years with the approval of relevant government departments (Cao, 2003).

In the Chinese housing market, real estate inputs and outputs have seen rapid growth in the past decade. Statistics show that the total completed investment and commercial housing sales increases from 3120.32 and 2506.82 billion yuan in 2008 to 10979.85 and 13370.13 billion yuan in 2017, respectively ${ }^{2}$. However, it is noteworthy that the growth rate of investment and housing sales both

\footnotetext{
2 Data source: http://www.stats.gov.cn/tjsj/ndsj/2017/indexch.htm
}

${ }^{*}$ Corresponding author. E-mail: glyang@casipm.ac.cn 


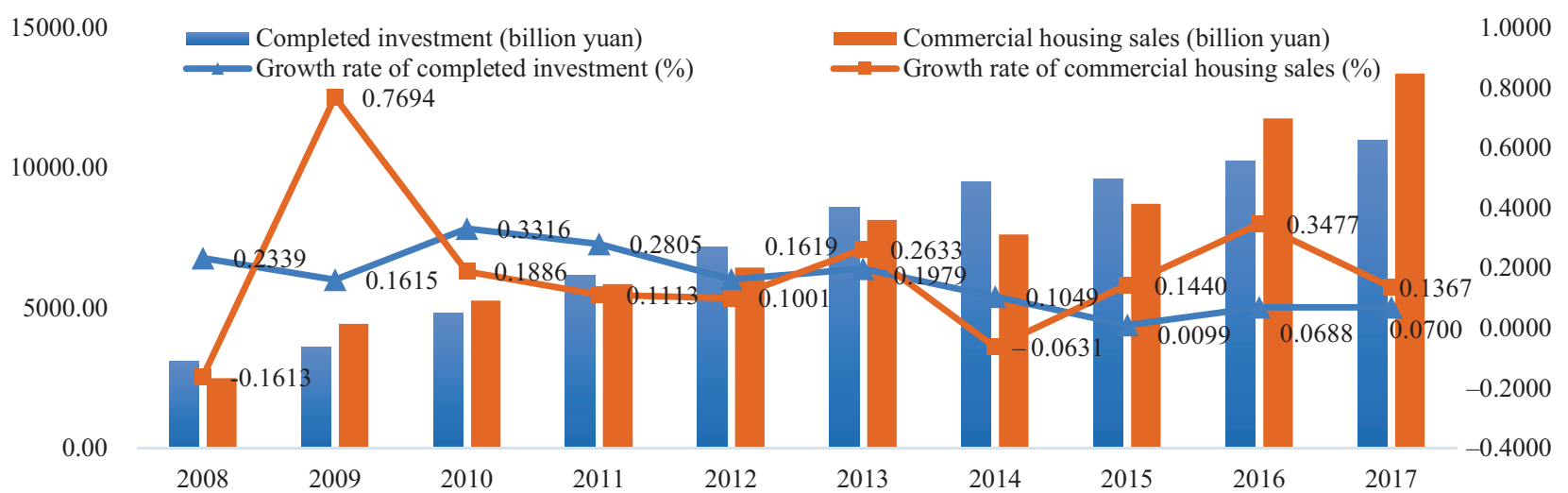

Figure 1. The trend of investment and sales in the real estate industry from 2008 to 2017

show an overall downward trend during the observation period, especially the sales one with dramatic fluctuation (see Figure 1). In this context of volatile real estate investment and sales growth, there is a need to investigate the real estate performance in China. About the real estate performance, this study mainly refers to the productivity (efficiency evolution or efficiency change) of the real estate industry based on the input and output indicators, which is a comprehensive index reflecting the technical level, management ability and product quality of the industry. Besides, as the development orientation and management mode of the real estate industry in China's provinces are differentiated, the provincial real estate productivity has more reference value for the local government to implement the real estate policy. Therefore, this study aims to measure the real estate productivity of 30 sample provinces on mainland China from 2008 to 2015.

In fact, the production process of the real estate industry is mainly divided into two stages, namely the development stage and the sales stage (see the logical model in Subsection 2.1). In the development stage (Stage 1), real estate enterprises are mainly engaged in the purchase of land use rights, land development, and housing construction. In the sales stage (Stage 2), enterprises are primarily involved in housing sales and market management. However, to the best of our knowledge, few studies evaluate the productivity of the Chinese real estate sector under the internal production structure (see the details of the literature review in Subsection 1.1). To fill this gap, we propose a two-stage framework to measure the real estate productivity in China.

For this purpose, this paper applies a common-weight global Malmquist productivity index (MPI) as the primary tool to measure the real estate productivity, which is based on the two-stage data envelopment analysis (DEA) method (see Subsection 1.2 for a literature review). As a nonparametric method, DEA is one of the most popular approaches to investigate the productivity of decisionmaking units (DMUs) (Emrouznejad \& Yang, 2018). The main contribution herein mainly includes the following aspects. First, we propose a two-stage logical model to simulate the production process of the real estate industry and then introduce the corresponding indicators of each stage. This two-stage logical model can not only clearly reflect the current situation of China's real estate productivity, but also can be used as a reference for the assessment of two-stage real estate performance in other countries and regions. Second, based on a common-weight global MPI, this paper makes a comprehensive empirical analysis of the real estate performance in 30 sample provinces of China from 2008 to 2015. We first estimate the real estate efficiency of the two stages to reveal the specific situation of each stage of the real estate sector in each province. Thus, based on the annual efficiency value, the provincial productivity from 2007 to 2015 is obtained to reflect the efficiency evolution of the real estate industry. Third, the dependence degree of the economy on the real estate industry refers to the ratio of real estate investment and Gross Domestic Product (GDP), which is developed to explore further the relationship between the real estate productivity to the provincial economy. Finally, we summarize the corresponding findings based on the empirical analysis and give some policy recommendations regarding the high-quality development of the Chinese real estate sector from the national, provincial, and enterprise perspectives.

The rest of this paper unfolds as follows. Section 1 reviews the previous literature on the performance assessment of the real estate sector and the two-stage DEA methods. A logical model of the real estate production process and its corresponding indicators used in this paper are presented in Section 2. Section 3 shows the empirical analysis with several discussions and recommendations. Conclusions are provided in the last section.

\section{Literature review}

\subsection{The real estate performance research}

The evaluation of the real estate performance has been widespread concerned by researchers, including economies of scale, investment efficiency, sustainable efficiency, destocking productivity, and other aspects. 
In the early research, the main concern is the economies of scale presenting in the real estate agency or the real estate investment trusts (REITs). Zumpano et al. (1993) propose that most residential real estate brokerage firms have economies of scale, and few firms are too small to achieve the cost reduction. Subsequently, Anderson et al. (1998) measure the operational efficiency of the real estate agency applying the basic DEA model and suggest that the unreasonable allocation of inputs leads to the inefficiency of these firms. Furthermore, Anderson et al. (2000) use the stochastic frontier approach (SFA) to measure the efficiency of the real estate brokerage companies and find that smaller companies are more efficient. Additionally, combining the overall efficiency and its decomposition (technical efficiency and scale efficiency), Anderson et al. (2002) evaluate the operational conditions of REITs and find that higher utilisation of inputs and larger scale of the company can present a higher efficiency. Considering the cost efficiency, Lewis et al. (2003) use the Bayesian SFA to measure the cost efficiency of REITs and suggest that the cost is efficient with facing the increasing returns to scale. But Miller and Springer (2007) extend the existing research on the operating efficiency of REITs and find that there are no determinants of economies of scale. This probably implies that the research results of scale economies are sensitive to the measurement methods (Bers \& Springer, 1997).

With the continuous development of real estate performance studies, the research contents are diversified, which mainly involves investment efficiency, operational efficiency, sustainable efficiency, destocking productivity, and supply-side efficiency of the real estate industry on the provincial or regional level. About the investment efficiency, Wang (2005) measures the government investment efficiency of the real estate sector in 31 China's provinces using a knowledge-based decision support system, which is based on the Charnes-Cooper-Rhodes (CCR) model, the Banker-Charnes-Cooper (BCC) model, and free disposal hull $(\mathrm{FDH})$ model of DEA. They report that this system converts digital data into information that can be used to evaluate potential real estate investment, so as to provide a reference for real estate investment reform for the government. Wei et al. (2011) investigate the real estate investment efficiency of 35 large and medium-sized cities in China, based on a super-efficiency DEA. The results show that excessive investment is the main reason leading to low investment efficiency. And the investment efficiency in China is characterized by regional differences. The investment efficiency of eastern coastal areas and northwest areas is higher than that of central regions. Kritikos et al. (2010) assess the efficiency of the real estate assets used within the units of a firm or across competing firms applying the CCR model, the BBC model, and the slacks-based measure model (SBM) of DEA. They report that scale inefficiency is the main reason for overall inefficiency, and the real estate portfolio needs to be reallocated.

In regards to the operational efficiency, $\mathrm{Li}$ (2008) calculates the operating efficiency of the real estate industry in 30 large and medium-sized cities in China using the cross efficiency DEA model, and the results show that the cross efficiency of 30 cities is distributed between 0.5 and 0.8. Among the effective cities based on the traditional CCR model, Guangzhou has the highest cross efficiency, and Shijiazhuang has the lowest cross efficiency. Zheng et al. (2011) figure out and rank the efficiency of the 94 Listed Real Estate Companies (LRECs) in China by the super-efficiency DEA model. The results indicate that the redundancy rate of the employee is $18.96 \%$, which is the main reason for the low efficiency. Chiang et al. (2016) investigate the operational efficiency of REITs in Singapore using the CCR model and the Tobit regression model and conclude that return on assets is positively correlated with the efficiency of REITs and negatively associated with debt ratio. Meanwhile, they report that the efficiency may not be affected by geographical diversification.

Additionally, in terms of the sustainable efficiency, Yang et al. (2018) measure the provincial sustainable efficiency of the Chinese real estate industry from 2007 to 2013 using a dynamic three-stage network SBM-DEA approach. They conclude that the real estate inefficiency is characterized by regional imbalance and has intensified across the provinces since 2012. Considering the destocking productivity, Chen et al. (2019) assess the Chinese real estate destocking productivity on the provincial level and municipal level, which is based on a MPI approach. They argue that the destocking productivity of central cities is better than that of other cities. Meanwhile, due to regional differences, the government cannot solve the real estate inventory problem through unified policies. About the supply-side efficiency, Li et al. (2019) measure the supplyside efficiency of the real estate sector in China's 29 provinces using the DEA model. They conclude that the main problem of low supply-side efficiency in China's real estate market is an oversupply of land, and the redundancy rate of land to de developed reaches $60.59 \%$.

Overall, the mainstream methods for evaluating real estate performance are nonparametric methods (e.g., DEA) and parametric methods (e.g., SFA), which have their features, mainly reflected in indicators, algorithm, noise, functional form, and factor weights (Lampe \& Hilgers, 2015). SFA decomposes the statistical noise from the inefficiency effect. However, it needs to set a specific function form in advance (Silva et al., 2016), and the unreasonable choice of function form will cause some errors to the estimation result (Avkiran \& Rowlands, 2008). In fact, DEA has several advantages in the evaluation of the real estate performance (Yang et al., 2018; Lampe \& Hilgers, 2015; Kao \& Hwang, 2008; Liu et al., 2019): (a) DEA does not need to set the specific function forms and weights in advance, so it avoids misspecification errors; (b) the estimation of real estate performance usually involves multiple inputs and multiple outputs, which can be well realized by DEA; (c) some DEA models can perform the intertemporal comparability of DMUs in the calculation of the real estate performance, which solve the problem that 
DMUs is not comparable across periods and accurately reveal the fluctuation trend of each DMU over time; and (d) because the real estate industry has a complex operating network, DEA can better simulate the production stage of the real estate industry, reveal the specific productivity of each stage, and identify the reasons that affect the development of the real estate industry. Therefore, this work aims to assess the productivity of China's provincial real estate industry by using a two-stage DEA method.

\subsection{Two-stage DEA model}

Since Charnes et al. (1978) propose the DEA model, it has been developed and applied rapidly (Emrouznejad \& Yang, 2018). DEA, as a nonparametric method, is an evaluation methodology based on the relative effectiveness of input and output. The conventional DEA model is regarded as a black box and cannot be known as the internal evaluation process. With the continuous improvement of the DEA-based model, the two-stage DEA is created, which can innovatively simulate the production process of the evaluated object. To wit, it refers to dividing the whole evaluation process into two stages, through which the specific reasons for the low efficiency of the evaluated object can be more clearly identified (Kao \& Hwang, 2008). Indicators of the two-stage DEA model are divided into three parts: inputs, intermediates, and outputs. Outputs of the first stage are used as inputs of the second stage, which are intermediates (Chen et al., 2009).

Different types of two-stage DEA models are put forward to solve specific efficiency evaluation problems. The original two-stage model refers to the kind of efficiency decomposition, which means the overall efficiency can be broken down into technical efficiency and scale efficiency (Banker et al., 1984). Seiford and Zhu (1999) propose a standard two-stage DEA model, which separately calculates the efficiency of the first stage and second stage independently. Subsequently, the internal relations between stages are considered. Färe and Grosskopf (2000) put forward the network DEA model, which further complicates the production structure. As for the classification of the network structure, the two-stage model is extended to the parallel structure (Kao, 2009) and series structure (Kao \& Hwang, 2008). About the specific mathematical model, there are some types of decomposition ways, such as multiplicative decomposition (Kao \& Hwang, 2008, 2014), additive decomposition (Chen et al., 2009), SBM (Tone \& Tsutsui, 2009, 2010, 2014) and so on. Among these above two-stage models, a multi-period two-stage DEA model introduced by Kao and Hwang (2014) can both measure the efficiency and its change (productivity) of each stage between the two periods.

Regarding the assessment of productivity (efficiency change), it is frequently estimated by MPI in some studies. The conventional concept of MPI is first introduced by Malmquist (1953) and then developed as a nonparametric approach (i.e., DEA) by Färe et al. (1994), which represents the total factor productivity between two time pe- riods. However, the conventional MPI presents the problem of non-circularity, which means its adjacent period components can give conflicting signals and lead to linear programming (LP) infeasibility. To solve this issue, Pastor and Lovell (2005) propose the global MPI. The global MPI and its components are circular; that is, it provides single measures of productivity and its components to solve LP infeasibility. Based on the aforementioned studies, Kao and Hwang (2014) propose a common-weight global MPI, which is based on the two-stage DEA model. The common-weight MPI uses the same frontier facet to calculate the productivity, and the results of different DMUs are more comparable to those calculated from the conventional MPI. Therefore, this paper utilises the two-stage common-weight global MPI, which can not only calculate the productivity in each stage, but also increase the comparability of the productivity between different periods by constructing the same frontier facet.

\subsection{A summary of the literature review}

From the perspective of application research (see the details in Subsection 1.1), there are three findings as follows. (a) more and more studies focus on real estate performance evaluation, such as scale efficiency, investment efficiency, operational efficiency, sustainable efficiency, destocking productivity, and supply-side efficiency, but few researchers carry on real estate productivity based on the two-stage production process; (b) considering that the real estate performance studies have certain reference value for the formulation of the real estate policy, some scholars select DMUs at the provincial or regional level; (c) DEA is prevalent in the performance evaluation of the real estate sector, which implicates that DEA is suitable for revealing the real estate performance (see Table A1 of Appendix).

From the perspective of methodology, we review a common-weight global MPI in Subsection 1.2, which is based on the two-stage DEA model. First, compared with the single-stage DEA model, the two-stage DEA model can more accurately simulate the production process of the real estate industry, reduce the error of the estimation results, and identify the inefficient production stage (the development stage or the sales stage). Second, under the two-stage DEA model, MPI can calculate the real estate productivity (efficiency change) based on the production process. Through the real estate productivity, the comparability of each DMU in each period can be enhanced, which is beneficial to reveal the development law of real estate industry over time and predict the future trend of real estate productivity in 30 sample provinces.

According to the above analysis, it's worth noting that few studies evaluate the real estate productivity through the internal investigation of the real estate production process. However, the estimation of real estate productivity, which considers the production stage, helps to identify the causes of low productivity and provide solutions for the improvement of the real estate industry. Therefore, we attempt to fill this gap by applying the common-weight 
global MPI based on the two-stage DEA model to assess the real estate productivity in Chinese 30 sample provinces (see the two-stage logical model of the real estate industry in the Subsection 2.1).

\section{Methodology}

\subsection{Logical model and notations}

The production system of the real estate industry is very complex, which involves land development, housing construction, market management, and intermediary services. However, the main process can be expressed as the development stage (Stage 1) and the sales stage (Stage 2). A two-stage production process is proposed to briefly estimate the real estate performance in this subsection (see Figure 2). In Stage 1, area of house under construction (AHC) and completed investment (CI) as the inputs are converted into the intermediates, which are completed housing area (CHA) and completed housing value (CHV). Stage 1 is the development process from the acquisition of building materials to the production of buildings. In Stage 2, CHA and CHV enter the housing market for sales and finally produce the outputs, which are commercial housing sales area (CHSA) and commercial housing sales (CHS). According to this logical model, we can comprehensively analyse the productivity of the Chinese real estate sector from three perspectives (i.e., the overall productivity, the development productivity in Stage 1, and the sales productivity in Stage 2). In particular, the overall productivity can reflect the overall development of the real estate sector during the observation period. The development productivity in Stage 1 can present the utilisation of resources in the production process, including the performance of capital utilisation and land use. The sales productivity in Stage 2 can show the current status of sales and management of the Chinese housing market. Additionally, notice that there are time lags in the real estate production process (Yang et al., 2018). Hence, we take into account the 2-year lag for the productivity evaluation of the Chinese real estate sector (see Figure 2).

As for the selection of indicators in the logical model, this paper refers to previous studies to define them. From the previous indicators listed in Table 1, we can summa- rise the main inputs into three categories (i.e., area indicator, investment indicator, and labour indicator) and the main outputs into two types (i.e., area indicator and sales indicator). Given this, we propose the two-stage production variables for this study as follows.

In Stage 1, we select the inputs (i.e., AHC and CI) from the perspective of area under construction and real estate investment. AHC refers to the total area under construction of all real estate enterprises in each province during the observation period, which is widely used for the real estate development evaluation in the previous studies (e.g., Wang, 2005; Wei et al., 2011; Li, 2008; Li et al., 2019; Yang et al., 2018). CI represents the total investment of all real estate enterprises engaged in real estate development in each province during the observation period, which is cited from the input indicator of Wang (2005), Wei et al. (2011), Li (2008), Li et al. (2019), and Yang et al. (2018).

In Stage 2, CHSA and CHS, as the outputs indicators, represent the sales area and sales of commercial housing. CHSA refers to the total area of commercial housing that has been formally contracted by real estate companies in each province in the statistical year, which are mainstream output indicators in Table 1 (see Wei et al., 2011; Chen et al., 2019; Li, 2008; Yang et al., 2018). CHS means the total contract value of commercial housing of all real estate firms in each province in the statistical year, which is based on the output indicator of Anderson et al. (1998), Wang (2005), and Wei et al. (2011).

About the intermediates, we find that a few studies take the production process into consideration in the estimation of real estate performance (see Table 1). However, based on the actual production process of the Chinese real estate enterprises, we can extract intermediates from the input or output indicators in previous studies. CHA represents the total area of the completed buildings in each province in the statistical year, which is shown in the inputs of Wang (2005) and the outputs of Li (2008). CHV means the construction value of the completed building, which is chosen from the perspective of the monetary indicator to increase the comparability of indicators between the two production stages in this study. The details of the explanations for all indicators used in this paper can be seen in Table 2.



Figure 2. The two-stage logical model of the real estate production process 
Table 1. A summary of the previous indicators selected in the real estate sector

\begin{tabular}{|c|c|c|c|c|}
\hline \multirow{2}{*}{$\begin{array}{l}\text { Author(s) } \\
\text { (Year) }\end{array}$} & \multirow{2}{*}{$\begin{array}{l}\text { Research field } \\
\text { and data }\end{array}$} & \multicolumn{3}{|c|}{ Indicators } \\
\hline & & Inputs & Intermediates & Outputs \\
\hline $\begin{array}{l}\text { Anderson } \\
\text { et al. (1998) }\end{array}$ & Firm-level & $\begin{array}{l}\text { (i) Salespersons; (ii) Nonsales } \\
\text { employees; (iii) Offices; } \\
\text { (iv) Advertising and promotion } \\
\text { expenses; (v) Other expenses }\end{array}$ & NA & $\begin{array}{l}\text { (i) Total revenue; (ii) Sales; } \\
\text { (iii) Listing transactions }\end{array}$ \\
\hline $\begin{array}{l}\text { Anderson } \\
\text { et al. }(2002)\end{array}$ & Firm-level & $\begin{array}{l}\text { (i) Total expenses (i.e., interest, oper- } \\
\text { ating cost, general and administrative } \\
\text { cost, and management cost) }\end{array}$ & NA & $\begin{array}{l}\text { (i) Total assets (i.e., mortgage } \\
\text { assets, equity assets, and others) }\end{array}$ \\
\hline Wang (2005) & Province-level & $\begin{array}{l}\text { (i) Real estate investment; (ii) Area } \\
\text { of purchased land; (iii) Area of } \\
\text { developed land; (iv) Area of } \\
\text { construction }\end{array}$ & NA & $\begin{array}{l}\text { (i) Housing sales; (ii) Land area } \\
\text { with finished construction; } \\
\text { (iii) Land Sales with finished } \\
\text { housing }\end{array}$ \\
\hline $\begin{array}{l}\text { Wei et al. } \\
(2011)\end{array}$ & City-level & $\begin{array}{l}\text { (i) Annual investment; (ii) Operated } \\
\text { area of commercial housing; } \\
\text { (iii) Employee }\end{array}$ & NA & $\begin{array}{l}\text { (i) Completed area of } \\
\text { commercial housing; (ii) Sales }\end{array}$ \\
\hline $\begin{array}{l}\text { Chen et al. } \\
\text { (2019) }\end{array}$ & Province-level & $\begin{array}{l}\text { (i) Labor; (ii) Asset; (iii) Residential } \\
\text { areas; (iv) Commercial areas }\end{array}$ & NA & $\begin{array}{l}\text { (i) Residential real estate sales } \\
\text { area; (ii) Commercial real estate } \\
\text { sales area }\end{array}$ \\
\hline Li (2008) & City-level & $\begin{array}{l}\text { (i) Speed of real estate investment; } \\
\text { (ii) Percentage of real estate in GDP; } \\
\text { (iii) New project area; (iv) Real estate } \\
\text { constructing area }\end{array}$ & NA & $\begin{array}{l}\text { (i) Accomplishment area; } \\
\text { (ii) Sales price; (iii) Sale area; } \\
\text { (iv) Controllable income of } \\
\text { customer; (v) Demand area of } \\
\text { customer }\end{array}$ \\
\hline $\begin{array}{l}\text { Zheng et al. } \\
(2011)\end{array}$ & Firm-level & $\begin{array}{l}\text { (i) Registered capital; (ii) Asset; } \\
\text { (iii) Employee; (iv) Operation cost }\end{array}$ & NA & (i) Revenue; (ii) Profit \\
\hline $\begin{array}{l}\text { Li et al. } \\
(2019)\end{array}$ & Province-level & $\begin{array}{l}\text { (i) Employees; (ii) The area of land } \\
\text { to be developed; (iii) Completed } \\
\text { investment; (iv) The net worth of } \\
\text { owned equipment and machinery }\end{array}$ & NA & $\begin{array}{l}\text { (i) Revenue from the principal } \\
\text { business of enterprises; (ii) The } \\
\text { added value of the real estate } \\
\text { industry }\end{array}$ \\
\hline $\begin{array}{l}\text { Yang et al. } \\
(2018)\end{array}$ & Province-level & $\begin{array}{l}\text { (i) Completed investment on } \\
\text { land; (ii) Assets; (iii) Labour; } \\
\text { (iv) Undeveloped land areas }\end{array}$ & $\begin{array}{l}\text { (i) Developing houses area; } \\
\text { (ii) Completed investment } \\
\text { in houses; (iii) Rent } \\
\text { areas; (iv) Completed } \\
\text { commercial housing areas }\end{array}$ & (i) Main business income \\
\hline
\end{tabular}

Table 2. The descriptions of the indicators used in this paper

\begin{tabular}{|c|c|c|c|c|}
\hline Indicator & Type & Unit & Notations & Explanation \\
\hline $\begin{array}{l}\text { Area of } \\
\text { house under } \\
\text { construction }\end{array}$ & Input & $\begin{array}{l}\text { Thousand } \\
\text { square metre }\end{array}$ & AHC & $\begin{array}{l}\text { It refers to the total area under construction by real estate } \\
\text { enterprises, which mainly includes the floor area of houses } \\
\text { newly commenced in the statistical year, and the floor area of } \\
\text { houses continued to be constructed in the previous year }\end{array}$ \\
\hline $\begin{array}{l}\text { Completed } \\
\text { investment }\end{array}$ & Input & Million yuan & CI & $\begin{array}{l}\text { The total investment makes by real estate enterprises in the year, } \\
\text { which includes investment in residential, commercial and other } \\
\text { buildings during the observation period }\end{array}$ \\
\hline $\begin{array}{l}\text { Completed } \\
\text { housing area }\end{array}$ & Intermediate & $\begin{array}{l}\text { Thousand } \\
\text { square metre }\end{array}$ & CHA & $\begin{array}{l}\text { It means the total area of the completed buildings in the } \\
\text { statistical year by real estate companies, which achieves } \\
\text { the standard for people to live in or use and has passed the } \\
\text { inspection after construction }\end{array}$ \\
\hline $\begin{array}{l}\text { Completed } \\
\text { housing value }\end{array}$ & Intermediate & Million yuan & $\mathrm{CHV}$ & $\begin{array}{l}\text { It means the construction value of the completed building, } \\
\text { which is calculated by the house design and budget }\end{array}$ \\
\hline $\begin{array}{l}\text { Commercial } \\
\text { housing sales area }\end{array}$ & Output & $\begin{array}{l}\text { Thousand } \\
\text { square metre }\end{array}$ & CHSA & $\begin{array}{l}\text { It refers to the total area of commercial housing that has } \\
\text { been formally contracted by real estate companies during the } \\
\text { observation period }\end{array}$ \\
\hline $\begin{array}{l}\text { Commercial } \\
\text { housing sales }\end{array}$ & Output & Million yuan & CHS & $\begin{array}{l}\text { It refers to the total contract value (i.e., the value of commercial } \\
\text { housing as designated in the contract) received from the sales of } \\
\text { the buildings during the observation year }\end{array}$ \\
\hline
\end{tabular}




\subsection{The common-weight global MPI}

To measure the productivity over the period in the twostage real estate production process, we apply the common-weight global MPI based on the two-stage DEA model. The specific formation process of the model is illustrated in the following.

Assume that there is a panel data set, with a sample of $j=1, \ldots, N$ DMUs (i.e., the provincial real estate sector in China) over $q$ time periods $(p=1, \ldots, q)$. The inputs, intermediates, and outputs of the Chinese real estate industry can be denoted as $x_{i j}^{p} \in \mathfrak{R}_{+}^{m}, z_{f j}^{p} \in \mathfrak{R}_{+}^{g}$, and $y_{r j}^{p} \in \mathfrak{R}_{+}^{s}$, respectively. And the totals of these variables can be represented as $x_{i j}=\sum_{p=1}^{q} x_{i j}^{p} z_{f j}=\sum_{p=1}^{q} z_{f j}^{p}$, and $y_{r j}=\sum_{p=1}^{q} y_{r j}^{p}$. Through the above defined symbols, the Production Possibility Set (PPS) can be expressed as $P P S=\left\{\left(x_{i j}^{p}, z_{f j}^{p}, y_{r j}^{p}\right) \mid x_{i j}^{p}\right.$ can produce $z_{f j}^{p}, z_{f j}^{p}$ can produce $\left.y_{r j}^{p}\right\}$.

As for the two-stage DEA model used in this paper, we first estimate the overall efficiency $E_{k}$, which can be regarded as the same frontier facet and is calculated from the totals of variables in all $q$ periods. Based on the overall efficiency $E_{k}$, we can get the productivity (i.e., the common-weight global $\mathrm{MPI}_{k}^{t, t+1}$ ). More specifically, to increase the comparability of efficiency between different DMUs, $E_{k}$ is used as the constraint in the evaluation of period $t$ efficiency $E_{k}^{t}$. Then the efficiency in stages $E_{1 k}^{t}$ and $E_{2 k}^{t}$ are calculated from $E_{k}^{t}$. Finally, the commonweight global $\mathrm{MPI}_{k}^{t, t+1}$ and its decomposition $M P I_{1 k}^{t, t+1}$ and $\mathrm{MPI}_{2 k}^{t, t+1}$ are derived from $E_{1 k}^{t}$ and $E_{2 k}^{t}$. The formation process of the common-weight global MPI is shown in Figure 3.

From the above calculation procedure, both the real estate efficiency and productivity in the two-stage produc-

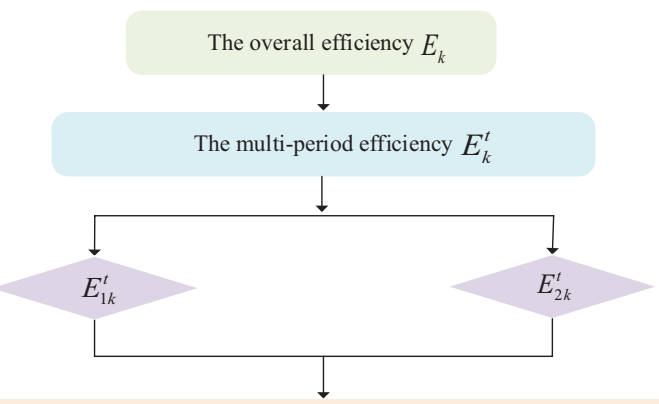

The common-weight global Malmquist productivity index $M P I_{k}^{t, t+1}$

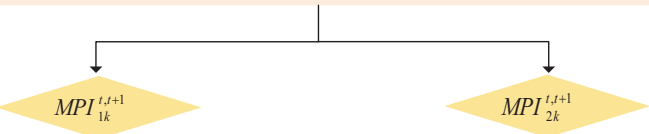

Figure 3. The formation process of the common-weight global MPI tion process can be evaluated. The formula of the overall efficiency $E_{k}$ is shown as follows:

$$
\text { s.t. }\left\{\begin{array}{c}
E_{k}=\max \sum_{r=1}^{s} u_{r} y_{r k} \\
\sum_{i=1}^{m} v_{i} x_{i k}=1 \\
\sum_{r=1}^{s} u_{r} y_{r j}^{p} \leq \sum_{i=1}^{m} v_{i} x_{i j}^{p} \\
\sum_{f=1}^{g} w_{f} z_{f j}^{p} \leq \sum_{i=1}^{m} v_{i} x_{i j}^{p} \\
\sum_{r=1}^{s} u_{r} y_{r j}^{p} \leq \sum_{f=1}^{g} w_{f} z_{f j}^{p} \\
j=1, \ldots, n, p=1, \ldots, q \\
i=1, \ldots, m, f=1, \ldots, g, r=1, \ldots, s \\
v_{i}, w_{f}, u_{r} \geq \varepsilon
\end{array},\right.
$$

where: $\varepsilon$ is the non-Archimedes infinitesimal; $v_{i}, w_{f}$ and $u_{r}$ are optimal multipliers. It is well known that DEA is a relative effectiveness evaluation method based on inputoutput data. In Model (1), $E_{k}$ is the relative efficiency of $\mathrm{DMU}_{\mathrm{k}}$, where $E_{k}$ equal to 1 indicates efficiency and $E_{k}$ less than 1 for inefficiency. In the two-stage production process, each DMU applies $m$ inputs to produce $g$ intermediates in Stage 1 and $g$ intermediates to produce $s$ outputs in Stage 2. Constraint 3 and 4 in Model (1) refers to the constraint that the weighted sum of intermediates is less than or equal to the weighted sum of inputs and the weighted sum of outputs is less than or equal to the weighted sum of intermediates, respectively. Since the sum of Constraint 3 and 4 is equal to Constraint 2 for each DMU, Constraint 2 is redundant and can be deleted. Additionally, considering Model (1) is a type of linear programming model of DEA, Constraint 1 is the constraint caused by Charnes-Cooper transformation of the objective function $E_{k}=\max \sum_{r=1}^{s} u_{r} y_{r k}$. Under the overall efficiency $E_{k}$, the efficiency value in period $t E_{k}^{t}$ can be expressed as:

$$
\left\{\begin{array}{c}
E_{k}^{t}=\max \sum_{r=1}^{s} u_{r} y_{r k}^{t} \\
\sum_{i=1}^{m} v_{i} x_{i k}^{t}=1 \\
\sum_{r=1}^{s} u_{r} y_{r k}=E_{k} \sum_{i=1}^{m} v_{i} x_{i k} \\
\sum_{r=1}^{s} u_{r} y_{r j}^{p} \leq \sum_{i=1}^{m} v_{i} x_{i j}^{p} \\
\sum_{f=1}^{g} w_{f} z_{f j}^{p} \leq \sum_{i=1}^{m} v_{i} x_{i j}^{p} \\
\sum_{r=1}^{s} u_{r} y_{r j}^{p} \leq \sum_{f=1}^{g} w_{f} z_{f j}^{p} \\
j=1, \ldots, n, p=1, \ldots, q \\
i=1, \ldots, m, f=1, \ldots, g, r=1, \ldots, s \\
v_{i}, w_{f}, u_{r} \geq \varepsilon
\end{array} .\right.
$$

Considering $E_{k}^{t}$ is derived from the overall efficiency $E_{k}$, the constraint condition $\sum_{r=1}^{s} u_{r} y_{r k}=E_{k} \sum_{i=1}^{m} v_{i} x_{i k}$ is added in Model (2) to construct the same frontier facet. Similarly, since the multi-period efficiency in stage $1 E_{1 k}^{t}$ is obtained from the multi-period efficiency $E_{k}^{t}$, the constraint condition $\sum_{r=1}^{s} u_{r} y_{r k}^{t}=E_{k}^{t} \sum_{i=1}^{m} v_{i} x_{i k}^{t}$ is added in 
Model (3) to form a common basis for comparison. In the two-stage production process, the efficiencies of the two sub-processes are also calculated. The multi-period model of Stage 1 is as follows:

$$
\text { s.t. }\left\{\begin{array}{c}
E_{1 k}^{t}=\max \sum_{r=1}^{s} u_{r} y_{r k}^{t} \\
\sum_{i=1}^{m} v_{i} x_{i k}^{t}=1 \\
\sum_{r=1}^{s} u_{r} y_{r k}=E_{k} \sum_{i=1}^{m} v_{i} x_{i k} \\
\sum_{r=1}^{s} u_{r} y_{r k}^{t}=E_{k}^{t} \sum_{i=1}^{m} v_{i} x_{i k}^{t} \\
\sum_{r=1}^{s} u_{r} y_{r j}^{p} \leq \sum_{i=1}^{m} v_{i} x_{i j}^{p} \\
\sum_{f=1}^{g} w_{f} z_{f j}^{p} \leq \sum_{i=1}^{m} v_{i} x_{i j}^{p} \\
\sum_{r=1}^{s} u_{r} y_{r j}^{p} \leq \sum_{f=1}^{g} w_{f} z_{f j}^{p} \\
j=1, \ldots, n, p=1, \ldots, q \\
i=1, \ldots, m, f=1, \ldots, g, r=1, \ldots, s \\
v_{i}, w_{f}, u_{r} \geq \varepsilon
\end{array} .\right.
$$

According to the equation of $E_{k}^{t}=E_{1 k}^{t} \times E_{2 k}^{t}$, we can get the multi-period efficiency in stage $2 E_{2 k}^{t}$. Finally, the model of the common-weight global MPI can be shown as the following equation:

$$
\begin{aligned}
& M P I_{k}^{t, t+1}=M P I_{1 k}^{t, t+1} \times M P I_{2 k}^{t, t+1} ; \\
& M P I_{k}^{t, t+1}=E_{k}^{t+1} / E_{k}^{t} \\
& M P I_{1 k}^{t, t+1}=E_{1 k}^{t+1} / E_{1 k}^{t} \\
& M P I_{2 k}^{t, t+1}=E_{2 k}^{t+1} / E_{2 k}^{t}
\end{aligned}
$$

Remark 1: Real estate performance is a general concept, specifically related to the real estate efficiency or efficiency change. For instance, Hu and Liu (2018) estimate the overall performance in the Chinese construction industry, which refers to the construction efficiency. Chen et al. (2019) measure the destocking performance of the real estate industry in China, which means the efficiency change of China's real estate inventory. Due to the evaluation of productivity (efficiency change) make multi-period performance research comparable, regulators use it as a reference indicator for policy making. Currently, a measure of MPI has been widely used as a guide to provide directions for achieving better performance. In this paper, the assessment of the real estate performance refers to the real estate productivity, which can be seen as the real estate efficiency change.

\section{Empirical analysis}

\subsection{Descriptive statistics on indicators}

The dataset selected in this paper is from the China Real Estate Statistical Yearbook 2008-2015. Due to the availability of data, we take 30 sample provinces (except Tibet) on mainland China as research objects. Notably, all the monetary indicators in this paper are deflated by the Consumer Price Index ${ }^{3}$ (CPI, index $2015=100$ ), which can avoid the error caused by inflation.

Through descriptive statistics, the trend of the provincial average value of the indicators selected in this paper can be demonstrated from 2008 to 2017. Figure 4(a) shows the tendency of the provincial average value of the area indicators (i.e., AHC, CHA, and CHSA). The trend of monetary indicators (i.e., CI, CHV, and CHS) is shown in Figure 4(b) (see the descriptive statistics in Table A2 of Appendix).

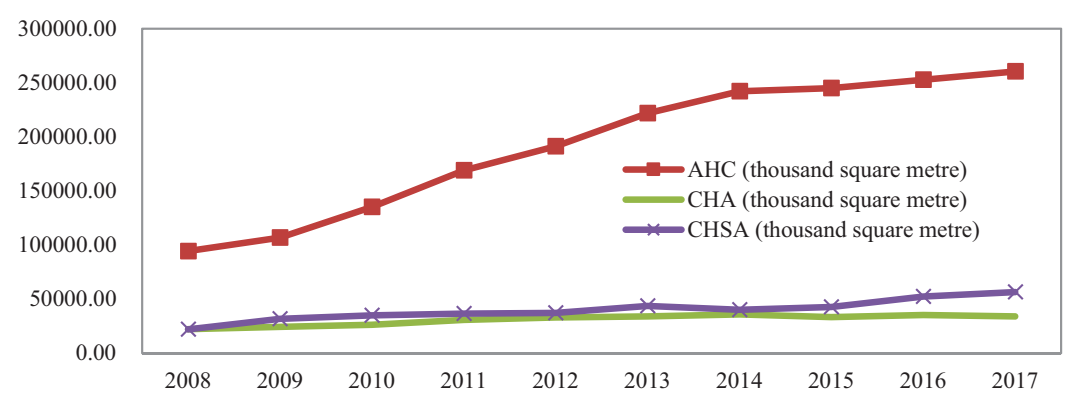

(a)

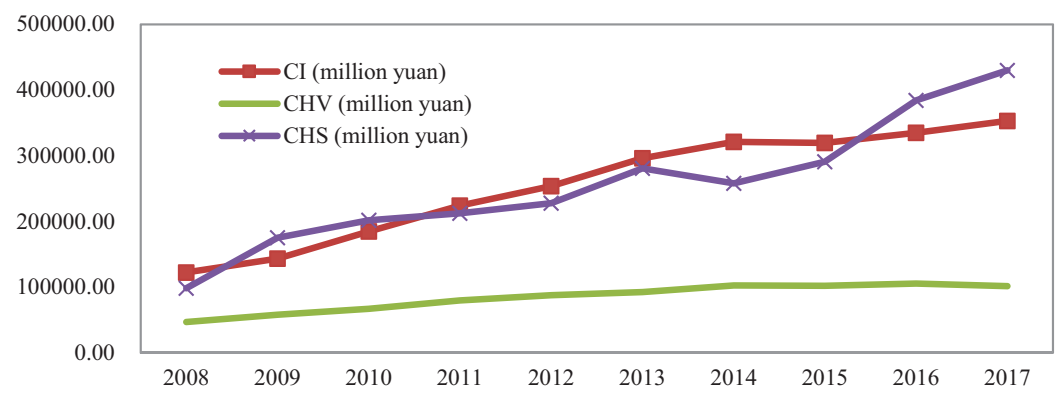

(b)

Figure 4. The trend of indicators used in this paper:

a) Average area indicators; b) Average monetary indicators

3 Note: The CPI is from the OECD database, https://data.oecd. org/price/inflation-cpi.htm\#indicator-chart. 
In Figure 4(a), there is more AHC than $\mathrm{CHA}$ and CHSA in each year, with a faster growth rate. AHC increases by 2.76 times between 2008 and 2017 (94373.86 vs. 260478.63 thousand square metres). Meanwhile, CHSA shows a growing trend within the statistical year, growing 2.57 times from 2008 to 2017. AHC represents the input of land area in the real estate sector, and CHSA is regarded as the output of the sales area in the housing market. The continuous growth of AHC and CHSA indicates that the rapid development of the Chinese real estate sector from 2008 to 2017. However, the average area of the completed buildings $\mathrm{CHA}$, as the intermediate, is smaller than AHC and CHSA and grows slowly during the observation pe$\operatorname{riod}(22163.40$ vs. 33814.28 thousand square metres).

From Figure 4(b), CI and CHS show an overall upward trend from 2008 to 2017. CI and CHS increase from 122369.18 million yuan and 98269.36 million yuan to 353147.20 million yuan and 430070.88 yuan. However, CHV rises from 46828.12 million yuan in 2008 to 101364.58 in 2017, and its growth rate is slow during the observation period. CI represents the capital input, and CHS shows the sales of the real estate market, while CHA expresses as the construction value in the development stage and building cost in the sales stage. According to $\mathrm{CI}$ and CHS, it shows a rapid growth trend in the housing market during the observation period. However, when combined with $\mathrm{CH}$ analysis, we can find that there may be a dangerous real estate bubble. That is, a large amount of money may pour into the housing market in China to make profits. Moreover, the growth trend of indicators used in this paper shows volatility during the observation period, which further implies that the development of the real estate industry in China is uneven. Therefore, it is necessary to measure real estate productivity under the two-stage production process.

\subsection{Empirical results}

In this subsection, the real estate productivity (i.e., the common-weight global MPI) of 30 sample provinces on mainland China is presented, which refers to the efficiency change in this paper and is based on the calculation of the overall efficiency and the multi-period efficiency (see Figure 3).

\subsubsection{The overall efficiency}

Based on Model (1), we get the overall efficiency for the Chinese real estate sector of 30 sample provinces (see Table 3). To facilitate analysis, we divide the results of 30 provinces into five intervals. The first interval is from 0.00 to 0.10 ; the second one is $0.1-0.15$; the third one is $0.15-$ 0.20 ; the fourth one is $0.20-0.25$; the fifth one is $0.25-0.35$ (see Table 4).

Initially, from Table 3, the overall efficiencies of 30 sample provinces are relatively low, and the average value is 0.1787 . Mainly, the maximum value is 0.3082 (Shanghai), and the minimum value is 0.1098 (Shanxi). Beijing (0.2702), Shanghai (0.3082), Guangdong (0.2590), and Hainan (0.2513) have developed well as a whole, followed by Zhejiang (0.2024), Tianjin (0.2083), and

Table 3. The overall efficiency of the provincial real estate industry in China

\begin{tabular}{|l|c|c|l|l|l|l|c|c|}
\hline \multicolumn{1}{|c|}{ Province } & $E_{k}$ & Rank & Province & $E_{k}$ & Rank & Province & $E_{k}$ & Rank \\
\hline Beijing & 0.2702 & 2 & Zhejiang & 0.2024 & 7 & Hainan & 0.2513 & 4 \\
\hline Tianjin & 0.2084 & 6 & Anhui & 0.1583 & 20 & Chongqing & 0.1535 & 21 \\
\hline Hebei & 0.1472 & 24 & Fujian & 0.1723 & 14 & Sichuan & 0.1746 & 13 \\
\hline Shanxi & 0.1098 & 30 & Jiangxi & 0.2278 & 5 & Guizhou & 0.1586 & 19 \\
\hline Inner Mongolia & 0.1323 & 28 & Shandong & 0.1631 & 16 & Yunnan & 0.1531 & 22 \\
\hline Liaoning & 0.1188 & 29 & Henan & 0.1878 & 11 & Shaanxi & 0.1362 & 27 \\
\hline Jilin & 0.1382 & 25 & Hubei & 0.1883 & 10 & Gansu & 0.1618 & 18 \\
\hline Heilongjiang & 0.1715 & 15 & Hunan & 0.1964 & 8 & Qinghai & 0.1373 & 26 \\
\hline Shanghai & 0.3083 & 1 & Guangdong & 0.2590 & 3 & Ningxia & 0.1475 & 23 \\
\hline Jiangsu & 0.1883 & 9 & Guangxi & 0.1622 & 17 & Xinjiang & 0.1767 & 12 \\
\hline
\end{tabular}

Table 4. The five intervals of the overall efficiency

\begin{tabular}{|c|l|}
\hline Interval & \multicolumn{1}{|c|}{ Provinces } \\
\hline $0.00-0.10$ & Tibet \\
\hline $0.10-0.15$ & Shanxi, Liaoning, Inner Mongolia, Shaanxi, Qinghai, Jilin, Hebei, Ningxia \\
\hline $0.15-0.20$ & $\begin{array}{l}\text { Yunnan, Chongqing, Anhui, Guizhou, Gansu, Guangxi, Shandong, Heilongjiang, Fujian, Sichuan, } \\
\text { Sichuan, Xinjiang, Henan, Jiangsu, Hubei, Hunan }\end{array}$ \\
\hline $0.20-0.25$ & Zhejiang, Tianjin, Jiangxi \\
\hline $0.25-0.35$ & Hainan, Guangdong, Beijing, Shanghai \\
\hline
\end{tabular}


Jiangxi (0.2278). Next, by segmenting the overall efficiency of 30 provinces in Table 4, we can see that most efficiency values are concentrated in the range of 0.15 to 0.20 , and they are positively related to their economic development status. Thus, it can be proposed that the overall efficiency of the real estate sector in China should be further improved in the future. Besides, the regional development of the housing market is unbalanced, which means that we need to combine the economic development of different regions for in-depth analysis.

\subsubsection{The multi-period two-stage efficiency}

According to Model (2) and Model (3), the multi-period two-stage efficiencies $E_{k}^{t}$ and its decompositions (the development efficiencies $E_{1 k}^{t}$ and the sales efficiencies $E_{2 k}^{t}$ ) of the real estate sector for 30 sample provinces can be calculated. Since the evaluation of the real estate performance in this paper takes into account the 2-year lag (see Subsection 2.1), we can only estimate the twostage efficiencies from 2008 to 2015 (see the details in Table A3 of Appendix).

First, the variations of the average multi-period efficiencies, the development efficiencies, and the sales efficiencies from 2008 to 2015 are clearly shown in Figure 5. According to Figure 5, it can be intuitively seen that: (a) the average multi-period efficiencies in the observation period are all lower than 0.4 and show a decreasing trend from 2008 to 2015; (b) the real estate development efficiencies are higher than these of the sales stage; (c) the trend of development efficiencies is relatively stable, but the trend of efficiencies in the sales stage fluctuates obviously. Based on the above three findings, we try to discuss the specific reasons for the inefficiency of the Chinese real estate sector from 2008 to 2015. Combined with the descriptive statistics in Subsection 3.1, the continuous increase of inputs (AHC and $\mathrm{CI}$ ) in the development stage does not promote the growth of intermediates (CHA and CHV). Hence, excessive inputs cannot improve the development efficiency in the statistical year. In the sales stage, with the continuous decline of intermediates (CHA and CHV) after 2014, the growth rate of outputs (CHSA and CHS) begins to accelerate, and the sales efficiency also gradually increased. Therefore, we believe that the appropriate reduction of intermediates is conducive to the improvement of sales efficiency. That is, the inefficiency in the sales stage is due to excess real estate inventory (i.e., CHA).
Second, we analyse the evaluation results of real estate efficiency in 30 provinces of China from the perspective of the production process (see Table 5). The average multi-period efficiencies of the 30 provinces are as low as the average value from 2008 to 2015, and the development efficiencies in most provinces are higher than these of the sales stage. Furthermore, we divide the provincial average efficiency value into four groups (see Figure 6). The interval of development efficiency and sales efficiency are $0.20-1.00$ and $0.20-0.60$, respectively. Group 1 contains the provinces with high development efficiency $(0.60-1.00)$ and high sales efficiency $(0.40-0.60)$. Group 2 refers to the provinces with high development efficiency $(0.60-1.00)$ and low sales efficiency $(0.20-0.40)$. Group 3 includes the provinces with low development efficiency $(0.20-0.60)$ and high sales efficiency $(0.40-0.60)$. Group 4 consists of the provinces with low development efficiency $(0.20-0.60)$ and low sales efficiency $(0.20-0.40)$.

1. In Group 1, there are only two provinces with high development efficiency and high sales efficiency, i.e., Hainan and Shanghai. As the provinces that implemented the real estate marketisation system in the early years, Hainan and Shanghai are more mature than other provinces in terms of real estate development and sales. That is, real estate enterprises in Hainan and Shanghai can generate relatively reasonable supply in the housing development stage and then meet the demand of the housing market in the sales stage. Besides, although both Hainan and Shanghai have higher efficiency than other provinces, they have different efficiency in specific production stages. The comparison between the two provinces shows that the development efficiency of Shanghai (0.8044) is higher than that of Hainan (0.7117). But the sales efficiency of Shanghai (0.4229) is lower than that of Hainan (0.5083). It indicates that the real estate sales market in Shanghai may have some real estate inventory, while there are excessive inputs (i.e., investment and land area under construction) in Hainan. In short, because of the causes of real estate inefficiency in different provinces, the real estate sector should take targeted measures.

2. Group 2 includes nine provinces with relatively high development efficiency but relatively low sales efficiency, which are Ningxia, Heilongjiang, Tianjin,

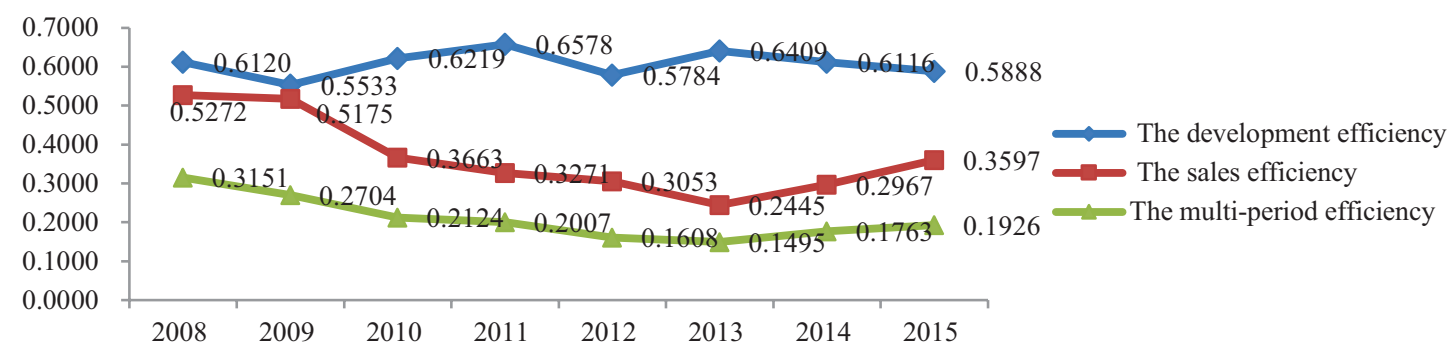

Figure 5. The average multi-period two-stage efficiency and its decompositions from 2008 to 2015 
Table 5. The average provincial multi-period two-stage efficiency and its decompositions

\begin{tabular}{|l|l|l|l|l|c|c|c|}
\hline \multicolumn{1}{|c|}{ Province } & $E_{1 k}{ }^{t}$ & $E_{2 k}{ }^{t}$ & $E_{k}{ }^{t}$ & \multicolumn{1}{c|}{ Province } & $E_{1 k}{ }^{t}$ & $E_{2 k}{ }^{t}$ & $E_{k}{ }^{t}$ \\
\hline Beijing & 0.5539 & 0.5379 & 0.2896 & Henan & 0.5549 & 0.4035 & 0.2058 \\
\hline Tianjin & 0.8745 & 0.2716 & 0.2360 & Hubei & 0.5858 & 0.3945 & 0.2160 \\
\hline Hebei & 0.5122 & 0.3494 & 0.1829 & Hunan & 0.6244 & 0.3496 & 0.2148 \\
\hline Shanxi & 0.6197 & 0.2310 & 0.1298 & Guangdong & 0.5529 & 0.4975 & 0.2681 \\
\hline Inner Mongolia & 0.5957 & 0.2852 & 0.1680 & Guangxi & 0.4169 & 0.4601 & 0.1803 \\
\hline Liaoning & 0.4905 & 0.2961 & 0.1468 & Hainan & 0.7117 & 0.5083 & 0.3288 \\
\hline Jilin & 0.6115 & 0.2982 & 0.1820 & Chongqing & 0.5956 & 0.3037 & 0.1772 \\
\hline Heilongjiang & 0.9112 & 0.2655 & 0.2497 & Sichuan & 0.5392 & 0.3692 & 0.1937 \\
\hline Shanghai & 0.8044 & 0.4229 & 0.3281 & Guizhou & 0.4897 & 0.4300 & 0.2052 \\
\hline Jiangsu & 0.7114 & 0.2923 & 0.2018 & Yunnan & 0.4287 & 0.4668 & 0.2011 \\
\hline Zhejiang & 0.5280 & 0.4420 & 0.2216 & Shaanxi & 0.3699 & 0.4630 & 0.1615 \\
\hline Anhui & 0.5630 & 0.3075 & 0.1704 & Gansu & 0.5577 & 0.3447 & 0.1899 \\
\hline Fujian & 0.4120 & 0.4993 & 0.1918 & Qinghai & 0.7936 & 0.2588 & 0.1842 \\
\hline Jiangxi & 0.5824 & 0.4310 & 0.2407 & Ningxia & 0.8712 & 0.2200 & 0.1981 \\
\hline Shandong & 0.5771 & 0.3380 & 0.1907 & Xinjiang & 0.8032 & 0.3036 & 0.2372 \\
\hline
\end{tabular}

Qinghai, Xinjiang, Jiangsu, Shanxi, Jilin, and Hunan. This means that the inputs (AHC and CI) of these provinces can produce relatively high intermediates (CHA and $\mathrm{CHV}$ ), while intermediates (CHA and $\mathrm{CHV}$ ) cannot create sufficient outputs (CHSA and CHS). The reasons for the relatively low sales efficiency in this group need to be analysed. Some provinces, such as Jiangsu, Tianjin, Hunan, and Shanxi, with the relatively high level of economic development, show high housing prices. Meanwhile, the housing supply structure in these provinces is inadequate to meet the needs of young workers for a small apartment. As a result, high housing prices and unreasonable housing supply structure for residents in these provinces lead to low commercial housing sales then generate low sales efficiency. On the contrary, the economic development of Ningxia, Heilongjiang, Qinghai, Xinjiang, and Jilin is relatively backward. Therefore, weak purchasing power in these provinces creates a sizeable real estate inventory, which in turn results in low sales efficiency.

3. Ten provinces are in Group 3, including Jiangxi, Guangdong, Beijing, Henan, Zhejiang, Guizhou, Yunnan, Guangxi, Fujian, and Shaanxi. These provinces have a low level of development efficiency but a high level of sales efficiency. Given this, it is essential to analyse the real estate development in these provinces. For these provinces such as Beijing, Zhejiang, Guangdong, Henan, and Fujian, there is a mass of speculative money going into the real estate development market. Excessive inputs in the development market lead to inefficient utilisation of resources and then make low development efficiency. However, the reasons for low development efficiency in Jiangxi, Guizhou, Yunnan, Guangxi,

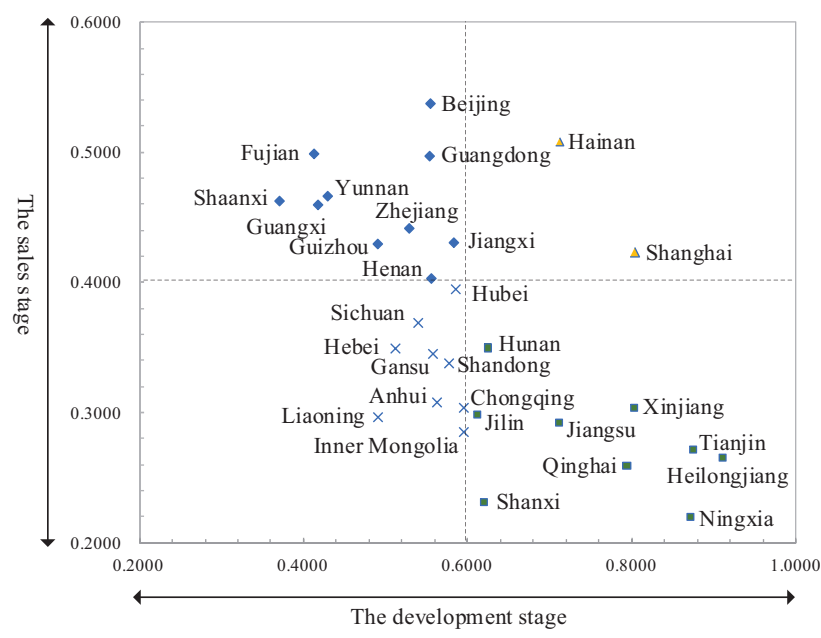

Figure 6. The chart of the provincial multi-period two-stage efficiency and its decompositions

and Shaanxi are the implementation of incentive real estate policies. The local government in these provinces attaches importance to the role of the real estate sector in promoting the growth of the economy. Consequently, the real estate industry in these provinces has been extensively developed.

4. There are nine provinces in Group 4, all of which show low efficiency in the development stage and sales stage. These provinces are Hubei, Inner Mongolia, Chongqing, Shandong, Anhui, Gansu, Sichuan, Hebei, and Liaoning. We think that the reasons for the real estate inefficiency in these provinces are diversified. It worth noting that the main reasons for low development efficiency contain unreasonable land resource management or immature construction technology in the development stage. And the low sales efficiency is mainly due to the 
incomplete system of real estate supply, the lack of demand from home buyers, or the inappropriate implementation of local government policies. Take Chongqing as an example. The real estate sector is an important driving force of economic growth in Chongqing. Meanwhile, under the relatively low utilisation rate $\left(64.08 \%{ }^{4}\right)$, people's housing demand in Chongqing is increasing. Considering such a situation, we believe that the unreasonable utilisation of real estate resources and the imperfect supply system are the main reasons for the inefficiency of development and sales in Chongqing.

\subsubsection{The common-weight global MPI}

Base on Equation (4)-(7), the productivity (i.e., the common-weight global MPI) and its decomposition (i.e., the development $\mathrm{MPI}_{1}$ and the sales $\mathrm{MPI}_{2}$ ) are used to measure the efficiency change of the Chinese real estate sector. In other words, MPI can be expressed as a comprehensive index, which measures the degree of the enhancement of enterprise technology, the improvement of market management, the upgrade of production quality, and the reform of organization structure. In this subsection, the common weight global MPI for the Chinese real estate sector that we applied can be analysed from the perspective of stages (Figure 7) and regions (Figure 9).

In terms of the analysis of the stages, we draw a figure with the average value of common-weight global MPI, development MPI 1 , and the sales $\mathrm{MPI}_{2}$ from 2008 to 2015. The following conclusions can be drawn from Figure 7: (a) the value of MPI shows an upward trend within the statistical year, but it also presents large volatility; (b) the value of MPI is lower than one from 2008 to 2013, while the value of MPI is larger than one from 2013 to 2015; (c) the tendency of $\mathrm{MPI}_{1}$ and $\mathrm{MPI}_{2}$ shows an opposite direction during the observation period, and the movement of MPI is almost the same as that of $\mathrm{MPI}_{2}$.
To further analyse the reasons for the fluctuation of MPI, we have to introduce the housing policies issued by the government, which have a critical impact on the real estate market. Firstly, with the improvement of housing policies and legal systems, companies continually promote their management ability and housing quality, which is reflected in the fact that the overall increase of MPI from 2008 to 2015. Secondly, policymakers have introduced a series of tax and monetary policies to intervene in the housing market, especially in the sales market. Given this, we can interpret the variation of MPI through policy implementation. Initially, the government conducts intensive regulations to cool the overheated housing market after 2008. For example, the State Council of the People's Republic of China issues "Regulations of the State Council on Promoting the Healthy Development of the Real Estate Market" (i.e., the four regulations of the real estate market) (SCC, 2009), "Notice of the State Council on Resolutely Curbing the Rapid Increase of Housing Prices in Some Cities" (i.e., the eight regulations of the real estate market) (SCC, 2010), and "Notice of the State Council on Further Improving the Regulations of the Real Estate Market" (i.e., the new eight regulations of the real estate market) (SCC, 2011) to control speculative investment and strengthen market supervision. Thus, these tightening real estate policies make MPI is lower than 1 . However, to stimulate the vitality of the housing market, the government begins to implement a series of loose real estate policies to meet the housing demand by reducing down-payment and increasing tax incentives after 2014. Such as "Notice on Further Improving Housing Finance Services" (PBC \& CBRC, 2014). Thirdly, with the real estate policies of restraining and then stimulating, the efficiency change in the development stage $\left(\mathrm{MPI}_{1}\right)$ and the sales stage $\left(\mathrm{MPI}_{2}\right)$ of the Chinese real estate sector are opposite. During the period of implementation of restraining policies, enterprises reduce real estate investment and land, and the development efficiency is improved, so

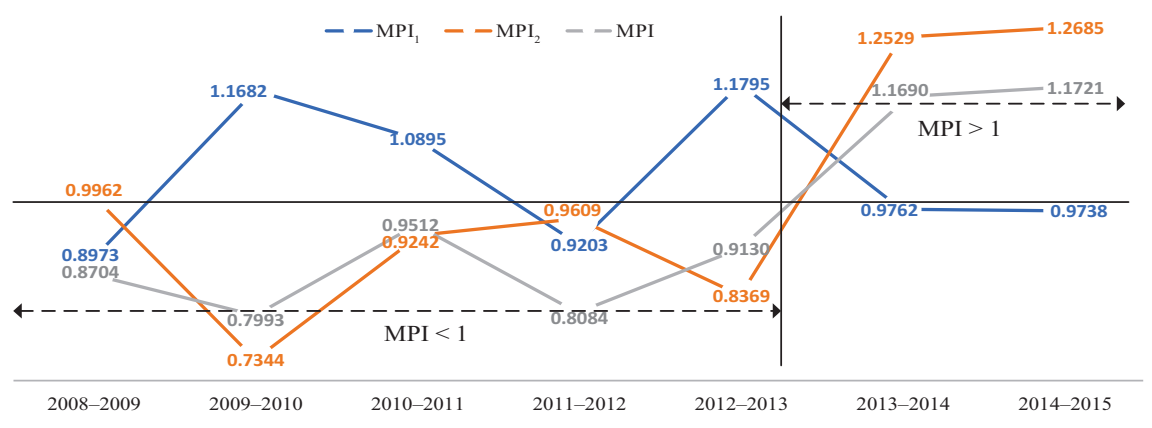

Figure 7. The line graph of the average common-weight global MPI and its decomposition from 2007 to 2015

\footnotetext{
4 Note: Urbanization rate in Chongqing in 2017.

http://www.stats.gov.cn/tjsj/ndsj/2018/indexch.htm
} 


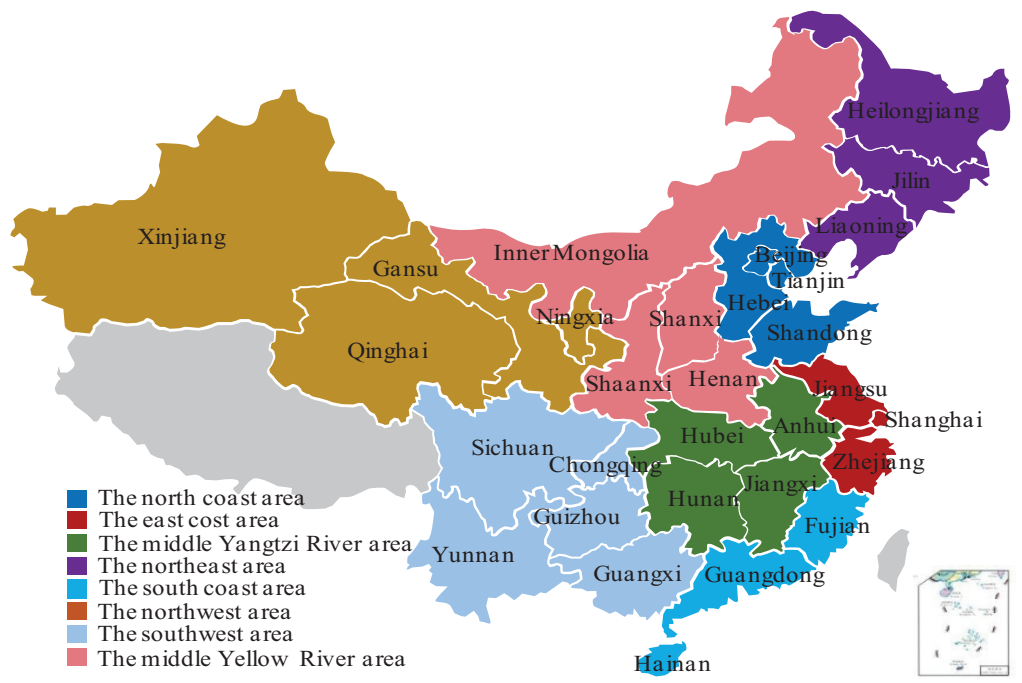

Figure 8. The division of eight economic-geographic regions in China

the values of $\mathrm{MPI}_{1}$ are almost higher than one from 2008 to 2013. Meanwhile, in the sales stage, real estate policies such as high-interest rate and high down payment ratio dampen the vitality of the sales market, so the values of $\mathrm{MPI}_{2}$ are less than 1 from 2008 to 2013. On the contrary, after the implementation of incentive policies, $\mathrm{MPI}_{1}$ is less than 1, while $\mathrm{MPI}_{2}$ are more significant than 1 from 2013 to 2015 .

Moreover, combined with the latest policies, we analyse the development trend of the Chinese real estate market in the future. Specifically, in December 2018, the Ministry of Housing and Urban-Rural Development of China (MOHURD) convene a conference on housing and urbanrural construction ${ }^{5}$. The meeting states that the Chinese government will focus on establishing and improving a long-term mechanism to ensure the high-quality development of the housing market. Specific measures include persisting in implementing targeted policies according to urban characteristics, improving the housing supply structure, and strengthening the supervision and administration of the market. Through the analysis of the above government policies, we believe that the policies will present diversified characteristics in the future, and not only limited to tax policies and financial policies. To be specific, the housing rental market will continue to develop, and the housing rental system will be perfect.

Next, the real estate sector, as a pillar industry in China, drives the increase of fiscal revenue, employment, and economic growth of most provinces. To analyse the impact of the real estate sector on China's economy, we refer to the division of China's regions proposed by Wang and Wei (2014) (see Figure 8) and divide 30 sample provinces in this paper into eight economic-geographic regions

\footnotetext{
5 Note: The conference on housing and urban-rural construction. http://www.gov.cn/xinwen/2018-12/25/content_5351829.htm
}

to further explore the information of the common-weight global MPI, the development MPI 1 , and the sales $\mathrm{MPI}_{2}$ from 2008 to 2015 (see the values in Table 6 and the variations in Figure 9).

From the line graph (Figure 9) of the average commonweight global MPI of the eight economic-geographic regions, we can find that: (a) the variations of the line graph of MPI, MPI ${ }_{1}$, and $\mathrm{MPI}_{2}$ in the eight economic-geographic regions from 2008 to 2015 are consistent with the overall trend in Figure 7; (b) the fluctuations of $\mathrm{MPI}_{1}$ in the eight economic-geographic regions are more smooth than those of $\mathrm{MPI}_{2}$; (c) the volatility of MPI is similar to that of $\mathrm{MPI}_{2}$, not MPI ${ }_{1}$. Given these findings, we can believe that $\mathrm{MPI}_{2}$ has a bigger influence on MPI, not MPI ${ }_{1}$, which indicates that the improvement of sales $\mathrm{MPI}_{2}$ may be conducive to the advancement of the whole real estate productivity.

As for the tendency of MPI in eight regions, it can be divided into two categories from Figure 9, namely, the type of first up and then down (Type 1: the east coast area, the north coast area, and the middle Yangtze River area) and the type of overall growth (Type 2: the northeast area, the south coast area, the northwest area, the southwest area, and the middle Yellow River area). Regions in Type 1 contain more developed provinces (e.g., Beijing, Shanghai Tianjin, Jiangsu, Zhejiang,) than other regions in Type 2. This illustrates that the real estate productivity in developed regions begins to decline after 2014 and further shows that the real estate market in developed regions may be close to saturation. However, the graphs of the undeveloped regions in Type 2 (e.g., the northeast area) show an overall upward trend of MPI, a relatively stable trend of $\mathrm{MPI}_{1}$, and an increasing trend of $\mathrm{MPI}_{2}$. The overall growth of $\mathrm{MPI}_{2}$ implies that there is still room for development in the sales market in these undeveloped regions. 
Table 6. The common-weight global MPI in eight regions from 2007 to 2015

\begin{tabular}{|c|c|c|c|c|c|c|c|c|}
\hline Stage & Region & 2008-2009 & $2009-2010$ & $2010-2011$ & 2011-2012 & $2012-2013$ & 2013-2014 & 2014-2015 \\
\hline \multirow[t]{8}{*}{ MPI } & The north coast area & 0.8636 & 0.8865 & 0.9104 & 0.8167 & 1.0246 & 1.3217 & 0.8896 \\
\hline & The east coast area & 0.7382 & 0.9334 & 1.0732 & 0.8129 & 1.1401 & 1.2453 & 0.9577 \\
\hline & The middle Yangtze River area & 0.9048 & 0.8362 & 1.0708 & 0.8599 & 0.8953 & 1.2313 & 1.1877 \\
\hline & The northeast area & 0.9472 & 0.7473 & 0.7049 & 0.6094 & 0.8299 & 1.2872 & 1.5967 \\
\hline & The south coast area & 0.8770 & 0.8629 & 1.0282 & 0.7529 & 0.8847 & 1.1495 & 1.2830 \\
\hline & The northwest area & 0.8870 & 0.6725 & 1.0388 & 0.8274 & 0.7710 & 0.9775 & 1.0620 \\
\hline & The southwest area & 0.8694 & 0.7702 & 0.8891 & 0.8470 & 0.9228 & 1.0531 & 1.2374 \\
\hline & The middle Yellow River area & 0.8637 & 0.7291 & 0.8977 & 0.8689 & 0.8619 & 1.1589 & 1.2265 \\
\hline \multirow[t]{8}{*}{$\mathrm{MPI}_{1}$} & The north coast area & 0.9878 & 1.0263 & 0.9945 & 0.8417 & 1.1240 & 1.1029 & 1.0592 \\
\hline & The east coast area & 0.9996 & 0.9972 & 1.2583 & 1.0703 & 1.1206 & 1.0265 & 1.0504 \\
\hline & The middle Yangtze River area & 0.8510 & 1.3175 & 1.1118 & 0.8594 & 1.0070 & 0.9712 & 0.9614 \\
\hline & The northeast area & 0.9950 & 1.1124 & 0.8210 & 1.0090 & 1.0072 & 0.9970 & 1.0505 \\
\hline & The south coast area & 1.0074 & 1.0271 & 1.1915 & 0.9527 & 1.9647 & 0.8063 & 0.9388 \\
\hline & The northwest area & 0.9508 & 1.2065 & 1.1272 & 0.8645 & 0.9941 & 0.9215 & 0.9975 \\
\hline & The southwest area & 0.7214 & 1.1330 & 1.1871 & 0.8280 & 1.1894 & 0.9907 & 0.8689 \\
\hline & The middle Yellow River area & 0.7867 & 1.4422 & 1.0003 & 1.0276 & 1.1647 & 0.9648 & 0.9195 \\
\hline \multirow[t]{8}{*}{$\mathrm{MPI}_{2}$} & The north coast area & 0.8896 & 0.8697 & 0.9347 & 1.0276 & 0.9119 & 1.1937 & 0.8722 \\
\hline & The east coast area & 0.7367 & 1.1115 & 0.9837 & 0.7914 & 1.0295 & 1.2537 & 0.8941 \\
\hline & The middle Yangtze River area & 1.0750 & 0.6501 & 0.9724 & 1.0144 & 0.9013 & 1.3218 & 1.3421 \\
\hline & The northeast area & 0.9607 & 0.6747 & 0.8851 & 0.6151 & 0.8766 & 1.3868 & 1.5206 \\
\hline & The south coast area & 0.8806 & 0.8819 & 1.0979 & 1.2832 & 0.5957 & 1.4447 & 1.3733 \\
\hline & The northwest area & 0.9315 & 0.5806 & 0.9398 & 0.9621 & 0.7979 & 1.1527 & 1.1526 \\
\hline & The southwest area & 1.2112 & 0.7161 & 0.7626 & 1.0399 & 0.7887 & 1.1030 & 1.5486 \\
\hline & The middle Yellow River area & 1.1282 & 0.5114 & 0.9064 & 0.8853 & 0.8033 & 1.2860 & 1.3701 \\
\hline
\end{tabular}

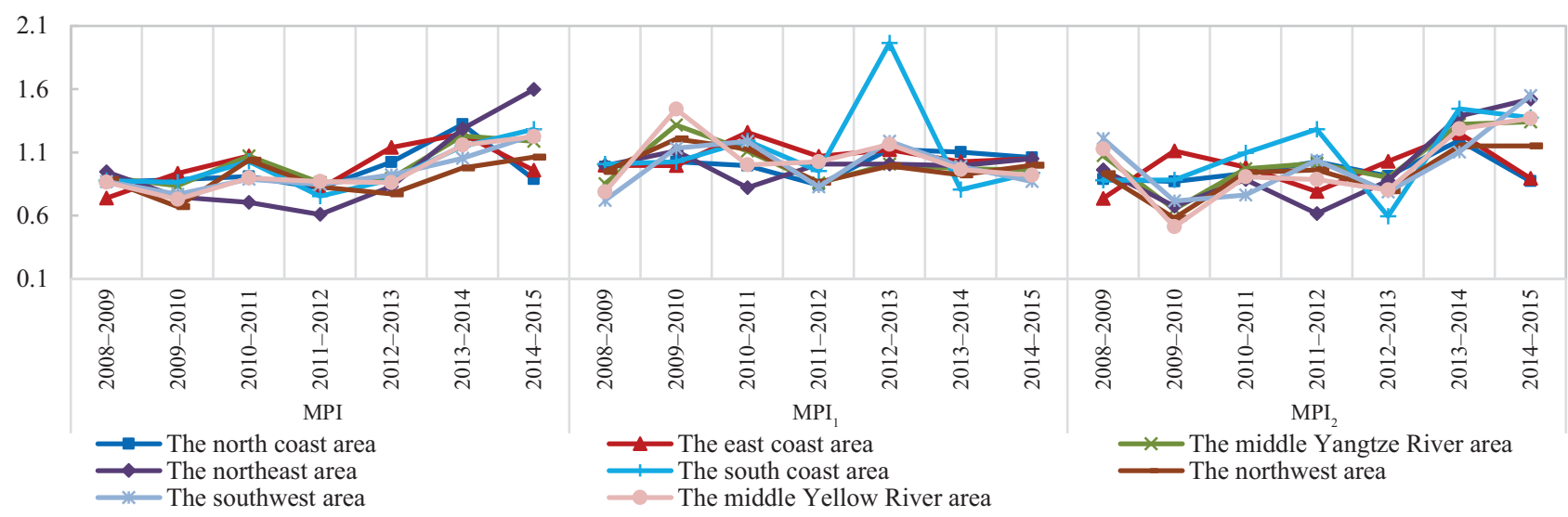

Figure 9. The line graph of the average common-weight global MPI and its decompositions

Besides, the variation of MPI in the south coast area shows an overall increasing trend, but the fluctuations of $M \mathrm{MI}_{1}$ and $\mathrm{MPI}_{2}$ are more violent than other regions in Type 2. In the south coast area, there are Fujian, Guangdong, and Hainan. By analyzing the $\mathrm{MPI}_{1}$ and $\mathrm{MPI}_{2}$ of these three provinces from 2008 to 2015 in Appendix Table A4, we find that the instability of $\mathrm{MPI}_{1}$ and $\mathrm{MPI}_{2}$ in Hainan mainly lead to the fluctuations of $\mathrm{MPI}_{1}$ and $\mathrm{MPI}_{2}$ in the south coast area. Moreover, it is noteworthy that Hainan actively carries out the reform of housing marketisation. Hence, we infer that the real estate development $\left(\mathrm{MPI}_{1}\right)$ and sales $\left(\mathrm{MPI}_{2}\right)$ in the Hainan are sensitive to the real estate policies mentioned in Subsection 3.2.3.

Furthermore, we introduce the concept of "the dependence degree of the economy on the real estate industry (DD)" to explore the relationship between the 


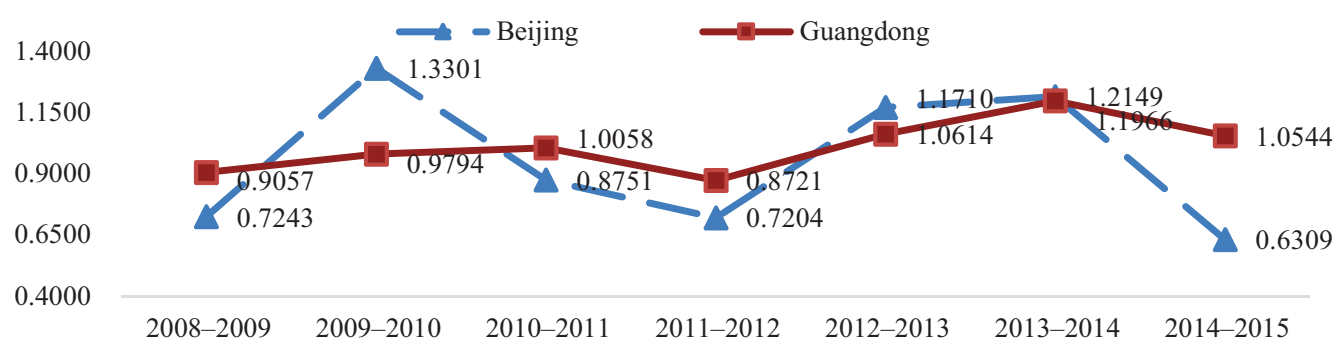

Figure 10. The line graph of the average common-weight global MPI of Beijing and Guangdong

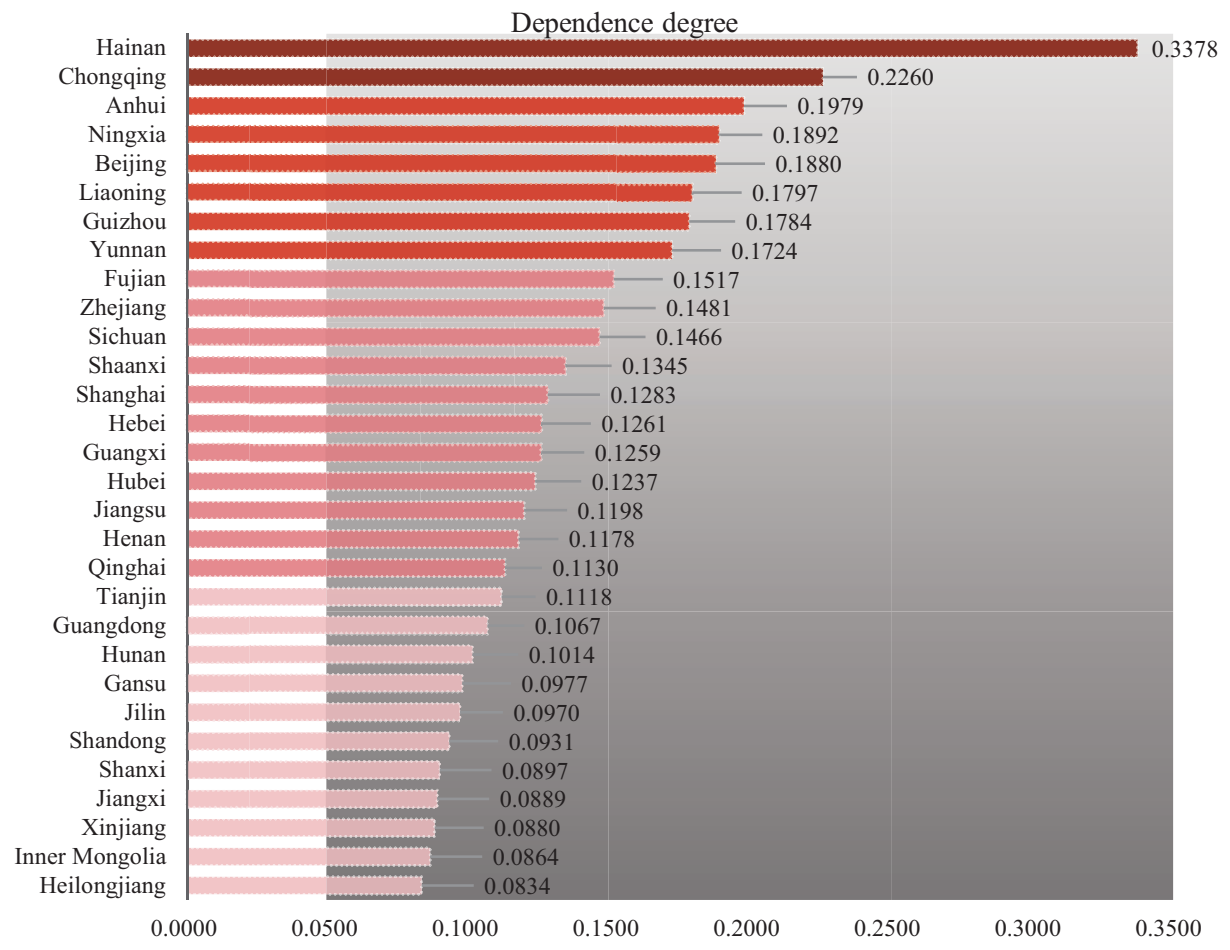

Figure 11. The average dependence degree of the economy on the real estate industry in China

provincial economy and the real estate productivity. Using data from the national bureau of statistics of China ${ }^{6}$, DD refers to the ratio of real estate investment and GDP. Figure 11 is a histogram of the average DD from 2008 to 2017. Given this figure, we can find that: (a) economic development of Hainan (0.3378) mainly depends on the real estate investment, followed by Chongqing (0.2260) and Anhui (0.1979); (b) compared with Shanghai (0.1283) and Zhejiang (0.1481), the economically developed provinces such as Beijing (0.1880) has a higher degree of dependence; (c) inversely, as a developed province in China, Guangdong has a lower value of DD. In light of these above findings, we can conclude that most of the developed provinces rely heavily on the real estate sector (e.g., Beijing). However, a few provinces start to wean themselves off the housing market (e.g., Guangdong). In particular, as the political and economic centre of China,

\footnotetext{
6 Data source: http://www.stats.gov.cn/tjsj/ndsj/2018/indexch.htm
}

a large number of speculative funds pour into Beijing's real estate market and then form a high DD. Meanwhile, the unstable investment leads to significant fluctuation in MPI from 2007 to 2015 (see Figure 10). Unlike Beijing, with the adjustment of the industrial structure in Guangdong, the economic development of Guangdong is more dependent on the electronic information industry, machinery industry, and textile industry rather than the real estate industry. Therefore, Guangdong presents a relatively lower DD than Beijing and then shows a smooth variation of MPI within the statistical year (see Figure 10).

Generally, China's economy is heavily dependent on the real estate sector. Still, a few provinces gradually get rid of the dependence of the housing market and then seek new development momentum. MPI, MPI ${ }_{1}$, and $\mathrm{MPI}_{2}$ in the regional real estate sector are relatively low from 2008 to 2015. However, there are specific measures that can be taken to improve the real estate productivity and then shift the real estate industry from extensive development 
to high-quality development. To wit, the real estate market in China may achieve high-quality growth through scientific and technological innovation and management innovation in the future.

\subsubsection{A summary of the major findings}

In the view of the literature in Subsection 1.1, some findings of real estate performance studies can be summarized as follows: (a) there has been some discussions about the scale efficiency of the real estate market, but no consistent conclusion has been reached (Anderson et al., 2000, 2002; Lewis et al., 2003; Miller \& Springer, 2007; Bers \& Springer, 1997; Kritikos et al., 2010); (b) some studies agree that serious imbalance exists in the Chinese provincial or regional real estate performance (Yang et al., 2018; Chen et al., 2019; Zheng et al., 2011); (c) as for the reasons of inefficiency, some studies argue that most of the low performance of real estate industry is caused by input redundancy, such as excessive investment or land (Anderson et al., 1998; Wei et al., 2011; Li et al., 2019). Compared with the prior studies, we not only discuss the provincial or regional difference of the real estate performance (i.e., Finding 3) and the reasons of the inefficiency of the real estate industry (i.e., Finding 1-2), but further discuss the real estate productivity based on the two-stage production process, such as the effect of real estate policy on the productivity (i.e., Finding 4) and a forecast of future trends in real estate productivity (i.e., Finding 5). Specifically, the major findings can be concluded as follows.

1. The overall efficiencies of the real estate sector in 30 sample provinces are low (see Subsection 3.2.1), ranging from 0.10 to 0.35 , and the efficiency values of most provinces are concentrated in the range from $0.15-0.20$. This indicates that the real estate efficiency in China needs to be improved urgently.

2. The variation of the average multi-period efficiencies shows an upward trend from 2008 to 2015, and the average sales efficiencies are all lower than the average development efficiencies within the statistical years (see Subsection 3.2.2). It implies that the improvement of sales efficiency is key to increase the real estate efficiency.

3. 30 provinces show different characteristics in terms of development efficiency and sales efficiency (see Subsection 3.2.2). There are specific reasons for real estate inefficiency in different provinces. This shows that policymakers can formulate real estate policies based on the situation of each province.

4. As for the common-weight global MPI, the fluctuations of MPI and $\mathrm{MPI}_{2}$ are similar from 2008 to 2016, and MPI's movements are consistent with the guidance of real estate policies (see Subsection 3.2.3). Hence, government regulations have a great influence on the development of the real estate sector in China.

5. In light of the regional analysis for MPI, we find that MPI in economically developed regions begins to decline between 2013 and 2014. However, MPI in non-economically developed regions still shows an overall increase from 2008 to 2015 (see Subsection 3.2.3). We predict that MPI in economically underdeveloped regions will decline in the future.

6. By exploring the impact of the real estate sector on the Chinese economy, MPI in most developed provinces with high DD is more significant than that in undeveloped provinces, but a few provinces have gradually begun to shake off their dependence on the real estate market (see Subsection 3.2.3). The real estate sector in China is promoting high-quality development.

\subsection{Policy implications and suggestions}

With the continuous improvement of China's utilisation, how to achieve high-quality development of the real estate industry should be widely concerned by policymakers. According to the above findings in Subsection 3.2.4, we can conclude that it is very necessary to promote the productivity of the Chinese real estate sector. The followings are policy recommendations, which are from the perspectives of the macro regulation by the central government, the specific implementation by the provincial government, and the improvement of enterprise innovation capability.

1. The policies issued by the central government play a guiding and regulating role in promoting the highquality development of the whole real estate industry in China. According to the empirical analysis, the average two-stage real estate efficiency and productivity are relatively low from 2008 to 2015 (see Figure 5 and Figure 7) and mainly caused by excessive inputs and unreasonable sales. Thus, facing weak real estate performance, the central government should emphasize curbing speculative investment and improve the structure of the housing supply for the real estate market. Meanwhile, "Houses are for the living, not for speculation." President Xi Jinping said at the central economic work conference in 2016. The central government has realised the direction of the development of the real estate sector. Therefore, the central government needs to rationalize real estate investment by establishing a diversified financing system (e.g., applying REITs to broaden financing channels, etc.). Next, regarding the housing sales market, the central government should encourage the diversification of supply structure by promoting the reform of the housing supply side (e.g., speeding up the renovation of shantytowns and improving community infrastructure facilities).

2. Considering that 30 provinces show different efficiency in the real estate development and sales stage (see Figure 6), the local governments should implement housing policies in line with their characteristics. 
- The provinces with relatively high development efficiency and high sales efficiency. Although both Hainan and Shanghai have higher efficiency than other provinces, the development efficiency of Shanghai (0.8044) is higher than that of Hainan (0.7117), while the sales efficiency of Shanghai (0.4229) is lower than that of Hainan (0.5083). Further analysis shows that Shanghai has real estate inventory, while there are an excessive investment and land area under construction in Hainan. Hence, the local government in Shanghai should improve the housing supply structure for real estate inventory. More specifically, the Shanghai government can provide tax incentives to encourage enterprises to build small-sized dwellings, which can alleviate the pressure on residents to buy houses due to high housing prices. However, the local government in Hainan needs to control the supply of the area of houses under construction (e.g., increasing the rate of value-added land tax) and resist speculative behaviours to avoid a large influx of hot money into the real estate development market (e.g., implementing the tight monetary policy).

- The provinces with relatively high development efficiency but low sales efficiency. Governments in these provinces should pay more attention to the sales market than the development market, which means excessive intermediates (i.e., completed housing area and value) cannot create sufficient outputs (commercial housing sales and sales area). For the developed provinces, such as Jiangsu, Tianjin, Hunan, and Shanxi. Due to the high housing prices and unreasonable housing supply structure, we argue that the local government needs to control excessive increases in housing prices through restrictive policies (e.g., increasing mortgage interest rates, etc.). Other provinces such as Ningxia, Heilongjiang, Qinghai, Xinjiang, and Jilin, in which the real estate market is relatively depressed, they need to stimulate residents' demand for housing through preferential purchase policies to alleviate the problem of real estate inventory. To be specific, they should first improve the system for the rental housing market to release real estate inventory and then reduce restrictions on house purchases and the proportion of down payments to motivate consumers to buy houses.

- The provinces with relatively low development efficiency but high sales efficiency. How to improve the development efficiency is the main task of the local government in this group. However, the way to enhance the development efficiency is different in these provinces. Considering the excessive investment in the development market in Beijing, Guangdong, Zhejiang, Fujian, and Henan, the local government should form the real estate financial market in line with the provincial characteristics and improve the supervision of the real estate development market (e.g., supervising the scale of assets and liabilities of real estate companies, etc.). However, the real estate market in Jiangxi, Guizhou, Yunnan, Guangxi, and Shaanxi has been extensively developed for the growth of the economy but ignore the management of the intermediate of completed buildings. The local government in these provinces need to reduce the economy's dependence on the real estate sector (e.g., exploring the development of emerging industries) and promote relevant standards for real estate development to build high-quality buildings (e.g., strengthening the supervision of the quality of construction projects, etc.).

- The provinces whose show low efficiency in both the development stage and sales stage. There are some provinces that need to strengthen both the development efficiency and sales efficiency, which means these provinces may face not only excessive investment, unreasonable land resource management, or immature construction technology in the development stage but also the incomplete system of real estate supply in the sales stage. Taking the degree of economic development and housing demand into account, these provinces can be divided into two types. For relatively developed provinces, such as Hubei, Chongqing, Anhui, Sichuan, and Hebei, the local government should improve development efficiency by controlling real estate financial risks (e.g., increasing the supervision of real estate loans from financial institutions) and improving the utilisation level of land resources (e.g., reforming the land approval system to prevent hoarding and speculation). Meanwhile, these provinces need to encourage real estate enterprises to develop housing types suitable for the residents of each province (e.g., public rental housing, mutual-property right housing. etc.). For relatively undeveloped provinces, such as Inner Mongolia, Gan$\mathrm{su}$, and Liaoning, these provinces should activate the real estate market by improving building technology standards (e.g., encouraging green building design and application of environmentally friendly materials) and introduce preferential policies to purchase houses (e.g., decreasing the proportion of down payment).

3. China's economy depends on the real estate industry to a certain extent (see Figure 11), so the real estate policy is widely used to macro-control the development of the housing market. This paper shows that government regulations have a significant influence on the fluctuation of MPI (Figure 7). Apart from the guidance of government policy, the innovation ability of real estate enterprises should be improved to achieve long-term stable development. As for the enhancement of the innovation ability, it mainly involves technological innovation, management innovation, innovation in finance, etc. First, technological innovation includes the improvement of green technology, intelligent technology, and security technology in the construction process. Second, management innovation refers to sales model innovation, human resource management innovation, and so on. Third, financing innovation refers to increasing real estate financing channels to form a comparatively complete financing framework. From the perspective of a two- 
stage production process, enterprises should respect the development rules of the industry and use technological innovation to promote new drivers of enterprise development in the real estate development stage. In the stage of real estate sales, enterprises need to develop diversified commercial houses to meet consumers' demands.

\section{Conclusions}

In this paper, indicators based on a common-weight global MPI including the two-stage efficiency and productivity are developed to measure the performance of the real estate sector in 30 sample provinces of China from 2008 to 2015. The two-stage productivity of the real estate industry is estimated by simulating the actual production process, which consists of the development stage and the sales stage. Based on the two-stage production process, the accuracy of the real estate productivity is improved, and the causes of low productivity are identified.

The major findings from the empirical analysis of this paper are summarized as follows: (1) the sales efficiency of the real estate sector in 30 sample provinces is lower than the development efficiency within the statistical years; (2) as for the common-weight global MPI, its movement is consistent with the guidance of real estate policies; (3) MPI in economically developed regions begins to decline between 2013 and 2014, but MPI in non-economically developed regions still shows an overall increase from 2008 to 2015. According to the above findings, we put forward some suggestions for policy implementations in Subsection 3.3. In short, in the context of China's economic transformation, we predict that the government will implement stricter policies to ensure the high-quality development of the real estate industry, which are from the perspectives of the macro regulation by the central government, the specific implementation by the provincial government, and the improvement of enterprise innovation capability.

Finally, most studies go through the four processes of data collection, information disclosure, intelligence analysis, and solution formation (DIIS) (Pan, 2019). This article is also based on the above four parts to complete the evaluation of China's provincial real estate productivity. However, considering that there are apparent differences in the productivity of the real estate industry in various regions, we need to continue in-depth research to consider further the impact of regional characteristics on the development of the Chinese real estate industry. Therefore, we plan to add the concept of meta-frontier DEA to measure the real estate productivity of each region in groups, so as to improve our research.

\section{Acknowledgements}

The authors would like to thank the editors of International Journal of Strategic Property Management and the two anonymous reviewers for their insightful comments and suggestions.

\section{Funding}

This work was supported by the $<$ National Natural Science Foundation of China> under Grant [number 71671181].

\section{Author contributions}

Xiao-xiao LIU Guo-liang YANG, and Jiao-feng PAN conceived the study and were responsible for summarizing and analyzing previous studies. Xiao-xiao LIU and Huihui LIU were responsible for data collection and analysis. Guo-liang YANG and Jiao-feng PAN were responsible for making policy recommendations. Xiao-xiao LIU wrote the first draft of the article.

\section{Disclosure statement}

The authors declare no conflict of interest.

\section{References}

Anderson, R. I., Fok, R., Springer, T., \& Webb, J. (2002). Technical efficiency and economies of scale: a non-parametric analysis of REIT operating efficiency. European Journal of Operational Research, 139(3), 598-612. https://doi.org/10.1016/S0377-2217(01)00183-7

Anderson, R. I., Fok, R., Zumpano, L. V., \& Elder, H. W. (1998). Measuring the efficiency of residential real estate. Journal of Real Estate Research, 16(2), 139-158.

Anderson, R. I., Lewis, D., \& Zumpano, L. V. (2000). X-Inefficiencies in the residential real estate market a stochastic frontier approach. Journal of Real Estate Research, 20(1), 93-103. https://doi.org/10.1023/A:1007889209994

Avkiran, N. K., \& Rowlands, T. (2008). How to better identify the true managerial performance: state of the art using DEA. Omega, 36, 317-324. https://doi.org/10.1016/j.omega.2006.01.002

Banker, R. D., Charnes, A., \& Cooper, W. (1984). Some models for estimating technical and scale inefficiencies in data envelopment analysis. Management Science, 30(9), 1078-1092. https://doi.org/10.1287/mnsc.30.9.1078

Bers, M., \& Springer, T. M. (1997). Economies of scale for real estate investment trusts. Journal of Real Estate Research, 14(3), 275-290.

Cao, Z. L. (2003). General theory of real estate economics (pp. 281-297). Peking University Press (in Chinese).

Charnes, A., Cooper, W. W., \& Rhodes, E. (1978). Measuring the efficiency of decision making units. European Journal of Operational Research, 2(6), 429-444. https://doi.org/10.1016/0377-2217(78)90138-8

Chen, K., Song, Y. Y., Pan, J. F., \& Yang, G. L. (2019). Measuring destocking performance of the Chinese real estate industry: a DEA-Malmquist approach. Socio-Economic Planning Sciences, 69, 100691. https://doi.org/10.1016/j.seps.2019.02.006

Chen, Y., Cook, W. D., Li, N., \& Zhu, J. (2009). Additive efficiency decomposition in two-stage DEA. European Journal of Operational Research, 196(3), 1170-1176. https://doi.org/10.1016/j.ejor.2008.05.011

Chiang, H. C., Tsaih, Y. C., \& Hsiao, W.-C. (2016). The efficiency analysis of Singapore real estate investment trusts. Eurasian Journal of Business and Management, 4(4), 9-20. https://doi.org/10.15604/ejbm.2016.04.04.002

Emrouznejad, A., \& Yang, G. L. (2018). A survey and analysis of the first 40 years of scholarly literature in DEA: 1978-2016. Socio-Economic Planning Sciences, 61, 4-8. https://doi.org/10.1016/j.seps.2017.01.008 
Färe, R., \& Grosskopf, S. (2000). Network DEA. Socio-Economic Planning Sciences, 34, 35-49. https://doi.org/10.1016/S0038-0121(99)00012-9

Färe, R., Grosskopf, S., Norris, M., \& Zhang, Z. (1994). Productivity growth, technical progress, and efficiency change in industrialised countries. American Economic Review, 84, 66-83.

$\mathrm{Hu}, \mathrm{X}$., \& Liu, C. (2018). Measuring efficiency, effectiveness and overall performance in the Chinese construction industry. Engineering, Construction and Architectural Management, 25(6), 780-797. https://doi.org/10.1108/ECAM-06-2016-0131

Kao, C. (2009). Efficiency measurement for parallel production systems. European Journal of Operational Research, 196(3), 1107-1112. https://doi.org/10.1016/j.ejor.2008.04.020

Kao, C., \& Hwang, S.-N. (2008). Efficiency decomposition in two-stage data envelopment analysis: an application to nonlife insurance companies in Taiwan. European Journal of Operational Research, 185(1), 418-429. https://doi.org/10.1016/j.ejor.2006.11.041

Kao, C., \& Hwang, S.-N. (2014). Multi-period efficiency and Malmquist productivity index in two-stage production systems. European Journal of Operational Research, 232(3), 512521. https://doi.org/10.1016/j.ejor.2013.07.030

Kritikos, M., Markellos, R., \& Prastacos, G. (2010). Corporate real estate analysis: evaluating telecom branch efficiency in Greece. Applied Economics, 42(9), 1133-1143. https://doi.org/10.1080/00036840701721166

Lampe, H. W., \& Hilgers, D. (2015). Trajectories of efficiency measurement: a bibliometric analysis of DEA and SFA. European Journal of Operational Research, 240(1), 1-21. https://doi.org/10.1016/j.ejor.2014.04.041

Lewis, D., Springer, T. M., \& Anderson, R. I. (2003). The cost efficiency of real estate investment trusts: an analysis with a Bayesian Stochastic Frontier Model. The Journal of Real Estate Finance and Economics, 26(1), 65-80.

https://doi.org/10.1023/A:1021522231824

Li, K., Ma, Z., \& Zhang, G. (2019). Evaluation of the supply-side efficiency of China's real estate market: a data envelopment analysis. Sustainability, 11(1), 288. https://doi.org/10.3390/su11010288

Li, N. (2008). Real estate cross-efficiency measurement based on peer appraisal DEA model and method in main cities of China. In 2008 International Conference on Management Science and Engineering 15th Annual Conference Proceedings, ICMSE (pp. 16671673). IEEE. https://doi.org/10.1109/ICMSE.2008.4669129

Liu, H., Yang, G., Liu, X., \& Song, Y. (2020). R\&D performance assessment of industrial enterprises in China: a two-stage DEA approach. Socio-Economic Planning Sciences, 71, 100753. https://doi.org/10.1016/j.seps.2019.100753

Malmquist, S. (1953). Index numbers and indifference surfaces. Trabajos de Estadistica, 4(2), 209-242. https://doi.org/10.1007/BF03006863

Miller, S. M., \& Springer, T. M. (2007). Cost improvements, returns to scale, and cost inefficiencies for real estate investment trust. SSRN Electronic Journal. https://doi.org/10.2139/ssrn.1006300

Pan, J. F. (2019). DIIS theory and methodology in think tank (pp. 8-18). Science Press (in Chinese).

Pastor, J. T., \& Lovell, C. A. K. (2005). A global Malmquist productivity index. Economics Letters, 88(2), 266-271. https://doi.org/10.1016/j.econlet.2005.02.013

PBC \& CBRC. (2014). People's Bank of China and China Banking Regulatory Commission: Notice on Further Improving Housing Finance Services (in Chinese). http://www.gov.cn/xinwen/2014-09/30/content_2759366.htm
SCC. (2009). State Council of the People's Republic of China: Regulations of the State Council on Promoting the Healthy Development of the Real Estate Market (in Chinese). http://www.gov.cn/ldhd/2009-12/14/content_1487025.htm

SCC. (2010). State Council of the People's Republic of China: Notice of the State Council on Resolutely Curbing the Rapid Increase of Housing Prices in Some Cities (in Chinese). http:// www.gov.cn/zwgk/2010-04/17/content_1584927.htm

SCC. (2011). State Council of the People's Republic of China: Notice of the State Council on Further Improving the Regulations of the Real Estate Market (in Chinese). http://www.gov.cn/zwgk/2011-01/27/content_1793578.htm

Seiford, L. M., \& Zhu, J. (1999). Profitability and marketability of the top 55 US commercial banks. Management Science, 45, 1270-1288. https://doi.org/10.1287/mnsc.45.9.1270

Shi, W., Chen, J., \& Wang, H. (2016). Affordable housing policy in China: new developments and new challenges. Habitat International, 54, 224-233.

https://doi.org/10.1016/j.habitatint.2015.11.020

Silva, T. C., Tabak, B. M., Cajueiro, D. O., \& Dias, M. V. B. (2016). A comparison of DEA and SFA using micro- and macro-level perspectives: efficiency of Chinese local banks. Physica A: Statistical Mechanics and its Applications, 469, 216-223.

https://doi.org/10.1016/j.physa.2016.11.041

Tone, K., \& Tsutsui, M. (2009). Network DEA: a slacks-based measure approach. European Journal of Operational Research, 197(1), 243-252. https://doi.org/10.1016/j.ejor.2008.05.027

Tone, K., \& Tsutsui, M. (2010). Dynamic DEA: a slacks-based measure approach. Omega, 38(3), 145-156. https://doi.org/10.1016/j.omega.2009.07.003

Tone, K., \& Tsutsui, M. (2014). Dynamic DEA with network structure: a slacks-based measure approach. Omega, 42(1), 124-131. https://doi.org/10.1016/j.omega.2013.04.002

Wang, J., Lin, Y., Glendinning, A., \& Xu, Y. (2018). Land-use changes and land policies evolution in China's urbanization processes. Land Use Policy, 75, 375-387. https://doi.org/10.1016/j.landusepol.2018.04.011

Wang, K., \& Wei, Y. M. (2014). China’s regional industrial energy efficiency and carbon emissions abatement costs. Applied Energy, 130, 617-631. https://doi.org/10.1016/j.apenergy.2014.03.010

Wang, W. K. (2005). A knowledge-based decision support system for measuring the performance of government real estate investment. Pergamon Press, 29(4), 901-912. https://doi.org/10.1016/j.eswa.2005.06.017

Wei, F., Li, Y., Gao, R., \& Sun, J. (2011). Study on the evaluation model of the investment efficiency of real estate industry based on super efficiency DEA. Applied Informatics and Communication, 111-118. https://doi.org/10.1007/978-3-642-23235-0_15

Yang, G. L., Fukuyama, H., \& Chen, K. (2018). Investigating the regional sustainable performance of the Chinese real estate industry: a slack-based DEA approach. Omega, 84, 141-159. https://doi.org/10.1016/j.omega.2018.04.009

Zheng, X., Chau, K. W., \& Hui, E. C. M. (2011). Efficiency assessment of listed real estate companies: an empirical study of China. International Journal of Strategic Property Management, 15(2), 91-104. https://doi.org/10.3846/1648715X.2011.582739

Zumpano, L. V., Elder, H. W., \& Crellin, G. E. (1993). The market for residential real estate brokerage services: costs of production and economies of scale. The Journal of Real Estate Finance and Economics, 6(3), 237-250. https://doi.org/10.1007/BF01096960 


\section{Appendix}

Table A1. Previous literature of the real estate performance research based on the DEA model

\begin{tabular}{|c|c|c|}
\hline Author(s) (Year) & Main research content & Method \\
\hline $\begin{array}{l}\text { Anderson et al. } \\
\text { (1998) }\end{array}$ & $\begin{array}{l}\text { It measures the efficiency of real estate agencies applying the DEA model and suggests } \\
\text { that the unreasonable allocation of inputs leads to the inefficiency of these firms }\end{array}$ & $\mathrm{CCR} / \mathrm{BCC}$ \\
\hline $\begin{array}{l}\text { Anderson et al. } \\
(2002)\end{array}$ & $\begin{array}{l}\text { This study evaluates the operational efficiency of REITs and finds that higher utilisation } \\
\text { of inputs and larger scale of the company can improve the operating efficiency }\end{array}$ & $\mathrm{CCR} / \mathrm{BCC}$ \\
\hline Wang (2005) & $\begin{array}{l}\text { This paper estimates the real estate performance of government investment and } \\
\text { proposes to reduce the investment and development area to improve efficiency }\end{array}$ & CCR/BCC/ FDH \\
\hline Wei et al. (2011) & $\begin{array}{l}\text { It evaluates the investment efficiency of the real estate market, which shows that the } \\
\text { investment is excessive, and the regional efficiency is not coordinated }\end{array}$ & Super-efficiency DEA \\
\hline $\begin{array}{l}\text { Kritikos et al. } \\
(2010)\end{array}$ & $\begin{array}{l}\text { It assesses the real estate assets efficiency in Greece and argues that the results can be } \\
\text { used as supporting information for managers to make decisions }\end{array}$ & $\mathrm{CCR} / \mathrm{BCC} / \mathrm{SBM}$ \\
\hline $\begin{array}{l}\text { Yang et al. } \\
\text { (2018) }\end{array}$ & $\begin{array}{l}\text { This paper proposes a network SBM model to measure the inefficiency of the provincial } \\
\text { housing market in China and argue that the inefficiency has worsened since } 2012\end{array}$ & SBM \\
\hline $\begin{array}{l}\text { Chen et al. } \\
(2019)\end{array}$ & $\begin{array}{l}\text { It uses a MPI approach to assess the Chinese real estate destocking performance and } \\
\text { find that the destocking issue in different cities in China cannot be solved by a unified } \\
\text { policy }\end{array}$ & MPI \\
\hline Li (2008) & $\begin{array}{l}\text { This paper calculates the operating efficiency of the real estate industry in } 30 \text { Chinese } \\
\text { cities, and the results show that the cross efficiency of } 30 \text { cities is distributed between } \\
0.5 \text { and } 0.8\end{array}$ & Cross efficiency DEA \\
\hline $\begin{array}{l}\text { Zheng et al. } \\
(2011)\end{array}$ & $\begin{array}{l}\text { This study uses the SE-DEA model to rank the performance of the evaluated LRECs in } \\
\text { China and then figure out the best LRECs }\end{array}$ & CCR/BCC/SE-DEA \\
\hline $\begin{array}{l}\text { Chiang et al. } \\
(2016)\end{array}$ & $\begin{array}{l}\text { This paper measures the operating efficiency of REITs in Singapore and finds that } \\
\text { return on assets is positively correlated with the efficiency but negatively correlated } \\
\text { with debt ratio }\end{array}$ & CCR \\
\hline Li et al. (2019) & $\begin{array}{l}\text { It measures the supply-side efficiency of the real estate sector in China's } 29 \text { provinces, } \\
\text { which conclude that the main problem of low supply-side efficiency is an oversupply } \\
\text { of land }\end{array}$ & $\mathrm{CCR} / \mathrm{BCC}$ \\
\hline
\end{tabular}

Table A2. Descriptive statistics of the real estate industry in China

\begin{tabular}{|c|l|c|c|c|c|c|c|}
\hline Years & Statistics & $\begin{array}{c}\text { Area of } \\
\text { house under } \\
\text { construction } \\
\text { (thousand square } \\
\text { metre) }\end{array}$ & $\begin{array}{c}\text { Completed } \\
\text { investment } \\
\text { (million yuan) }\end{array}$ & $\begin{array}{c}\text { Completed } \\
\text { housing area } \\
\text { (thousand square } \\
\text { metre) }\end{array}$ & $\begin{array}{c}\text { Completed } \\
\text { housing value } \\
\text { (million yuan) }\end{array}$ & $\begin{array}{c}\text { Commercial } \\
\text { housing sales } \\
\text { area (thousand } \\
\text { square metre) }\end{array}$ & $\begin{array}{c}\text { Commercial } \\
\text { housing sales } \\
\text { (million yuan) }\end{array}$ \\
\hline \multirow{2}{*}{2008} & Max & 289633.35 & 388954.67 & 82655.30 & 182655.04 & 60918.64 & 339965.91 \\
\cline { 2 - 9 } & Min & 6982.11 & 6024.96 & 2253.03 & 4231.52 & 1478.92 & 4281.37 \\
\cline { 2 - 9 } & Median & 74497.91 & 97392.68 & 18527.63 & 35886.19 & 17478.21 & 70997.56 \\
\cline { 2 - 9 } & Mean & 94373.86 & 122369.18 & 22163.40 & 46828.12 & 21967.78 & 98269.36 \\
\cline { 2 - 9 } & Std. Dev. & 68710.75 & 96453.10 & 17064.27 & 42751.92 & 14707.89 & 85898.74 \\
\hline \multirow{2}{*}{2009} & Max & 299538.86 & 395837.99 & 84428.03 & 228380.98 & 102481.99 & 605450.51 \\
\cline { 2 - 9 } & Min & 9003.88 & 8637.65 & 1819.83 & 3386.04 & 2168.21 & 6470.96 \\
\cline { 2 - 9 } & Median & 89462.97 & 120121.51 & 21583.48 & 49955.85 & 24827.20 & 112735.82 \\
\cline { 2 - 9 } & Mean & 106742.51 & 143174.69 & 24210.48 & 58023.04 & 31563.92 & 175241.71 \\
\cline { 2 - 9 } & Std. Dev. & 72363.64 & 104146.80 & 17315.22 & 47928.17 & 22655.63 & 170662.82 \\
\hline
\end{tabular}


End of Table A2

\begin{tabular}{|c|c|c|c|c|c|c|c|}
\hline Years & Statistics & $\begin{array}{c}\text { Area of } \\
\text { house under } \\
\text { construction } \\
\text { (thousand square } \\
\text { metre) }\end{array}$ & $\begin{array}{c}\text { Completed } \\
\text { investment } \\
\text { (million yuan) }\end{array}$ & $\begin{array}{c}\text { Completed } \\
\text { housing area } \\
\text { (thousand square } \\
\text { metre) }\end{array}$ & $\begin{array}{l}\text { Completed } \\
\text { housing value } \\
\text { (million yuan) }\end{array}$ & $\begin{array}{l}\text { Commercial } \\
\text { housing sales } \\
\text { area (thousand } \\
\text { square metre) }\end{array}$ & $\begin{array}{c}\text { Commercial } \\
\text { housing sales } \\
\text { (million yuan) }\end{array}$ \\
\hline \multirow[t]{5}{*}{2010} & Max & 351069.04 & 494067.87 & 86962.78 & 265142.50 & 94854.73 & 636671.90 \\
\hline & Min & 14242.27 & 12432.62 & 2676.73 & 5727.81 & 2810.44 & 9703.70 \\
\hline & Median & 114151.86 & 153717.22 & 22700.62 & 58560.32 & 27574.34 & 147073.85 \\
\hline & Mean & 135093.71 & 184825.10 & 26243.90 & 67187.70 & 34915.12 & 201929.28 \\
\hline & Std. Dev. & 88404.34 & 130424.73 & 18150.78 & 54904.10 & 24281.89 & 169096.84 \\
\hline \multirow[t]{5}{*}{2011} & Max & 405002.66 & 606199.66 & 84482.38 & 244095.17 & 95760.08 & 637184.70 \\
\hline & Min & 16660.49 & 15753.25 & 4492.53 & 13809.66 & 3595.59 & 12715.06 \\
\hline & Median & 134776.19 & 192432.22 & 24518.57 & 63490.05 & 31373.27 & 183327.86 \\
\hline & Mean & 168908.92 & 224248.78 & 30866.08 & 79733.61 & 36449.50 & 212602.13 \\
\hline & Std. Dev. & 108090.32 & 156398.54 & 20107.72 & 57222.19 & 24306.05 & 155072.22 \\
\hline \multirow[t]{5}{*}{2012} & Max & 450975.38 & 658471.65 & 98484.03 & 291449.02 & 90191.80 & 679873.86 \\
\hline & Min & 18912.26 & 20125.15 & 4162.03 & 11447.48 & 2629.57 & 11295.41 \\
\hline & Median & 152145.15 & 214666.05 & 24199.95 & 68203.26 & 29985.02 & 190159.17 \\
\hline & Mean & 191123.40 & 253923.66 & 33138.58 & 87826.21 & 37093.72 & 227934.33 \\
\hline & Std. Dev. & 118932.14 & 173165.17 & 22354.33 & 63443.60 & 24949.47 & 172598.96 \\
\hline \multirow[t]{5}{*}{2013} & Max & 525741.74 & 748702.56 & 97115.97 & 307641.65 & 114547.74 & 924426.50 \\
\hline & Min & 23766.42 & 25601.10 & 5926.22 & 16621.17 & 3815.58 & 16422.58 \\
\hline & Median & 178088.38 & 264508.52 & 27358.61 & 75075.99 & 32381.80 & 215753.71 \\
\hline & Mean & 221838.06 & 296400.97 & 33805.63 & 92360.11 & 43508.40 & 280595.82 \\
\hline & Std. Dev. & 136838.37 & 199301.42 & 21872.90 & 65735.56 & 29897.83 & 220907.69 \\
\hline \multirow[t]{5}{*}{2014} & Max & 576377.19 & 835891.32 & 96204.75 & 302106.92 & 98468.37 & 858372.47 \\
\hline & Min & 25459.02 & 31271.07 & 5594.87 & 16250.76 & 4157.71 & 21431.26 \\
\hline & Median & 197503.40 & 290638.08 & 29628.60 & 83335.87 & 31673.35 & 198867.72 \\
\hline & Mean & 242069.72 & 321169.63 & 35802.19 & 102275.82 & 40196.40 & 257855.40 \\
\hline & Std. Dev. & 149344.76 & 217851.51 & 23179.14 & 70718.26 & 26867.57 & 195190.39 \\
\hline \multirow[t]{5}{*}{2015} & Max & 581184.40 & 853847.00 & 102969.60 & 350300.00 & 116810.10 & 1144280.00 \\
\hline & Min & 25855.90 & 33600.00 & 4544.10 & 12036.00 & 3929.60 & 20600.00 \\
\hline & Median & 207371.80 & 264138.00 & 27161.75 & 88835.00 & 35008.20 & 205932.00 \\
\hline & Mean & 245104.24 & 319762.83 & 33315.62 & 101739.10 & 42814.56 & 290865.87 \\
\hline & Std. Dev. & 153478.41 & 220708.90 & 22388.56 & 74046.25 & 31123.16 & 250304.74 \\
\hline \multirow[t]{5}{*}{2016} & Max & 642338.00 & 1010568.63 & 100739.60 & 360611.76 & 146116.00 & 1589667.65 \\
\hline & Min & 28477.10 & 38913.73 & 3866.70 & 10920.59 & 4378.50 & 23180.39 \\
\hline & Median & 208639.20 & 265935.78 & 26171.15 & 79812.25 & 39344.15 & 299527.94 \\
\hline & Mean & 252875.35 & 335072.09 & 35365.39 & 105365.72 & 52424.64 & 384277.42 \\
\hline & Std. Dev. & 164216.91 & 245622.96 & 24517.63 & 82902.42 & 39528.79 & 355827.31 \\
\hline \multirow[t]{5}{*}{2017} & Max & 724921.00 & 1165607.14 & 95817.30 & 331018.34 & 159588.10 & 1813972.97 \\
\hline & Min & 29367.10 & 39439.19 & 4409.00 & 13270.27 & 4940.40 & 28619.69 \\
\hline & Median & 218874.85 & 284180.50 & 24058.40 & 71578.67 & 45120.40 & 280534.27 \\
\hline & Mean & 260478.63 & 353147.20 & 33814.28 & 101364.58 & 56451.52 & 430070.88 \\
\hline & Std. Dev. & 176570.24 & 274433.40 & 24470.51 & 82085.04 & 44216.97 & 402285.71 \\
\hline
\end{tabular}




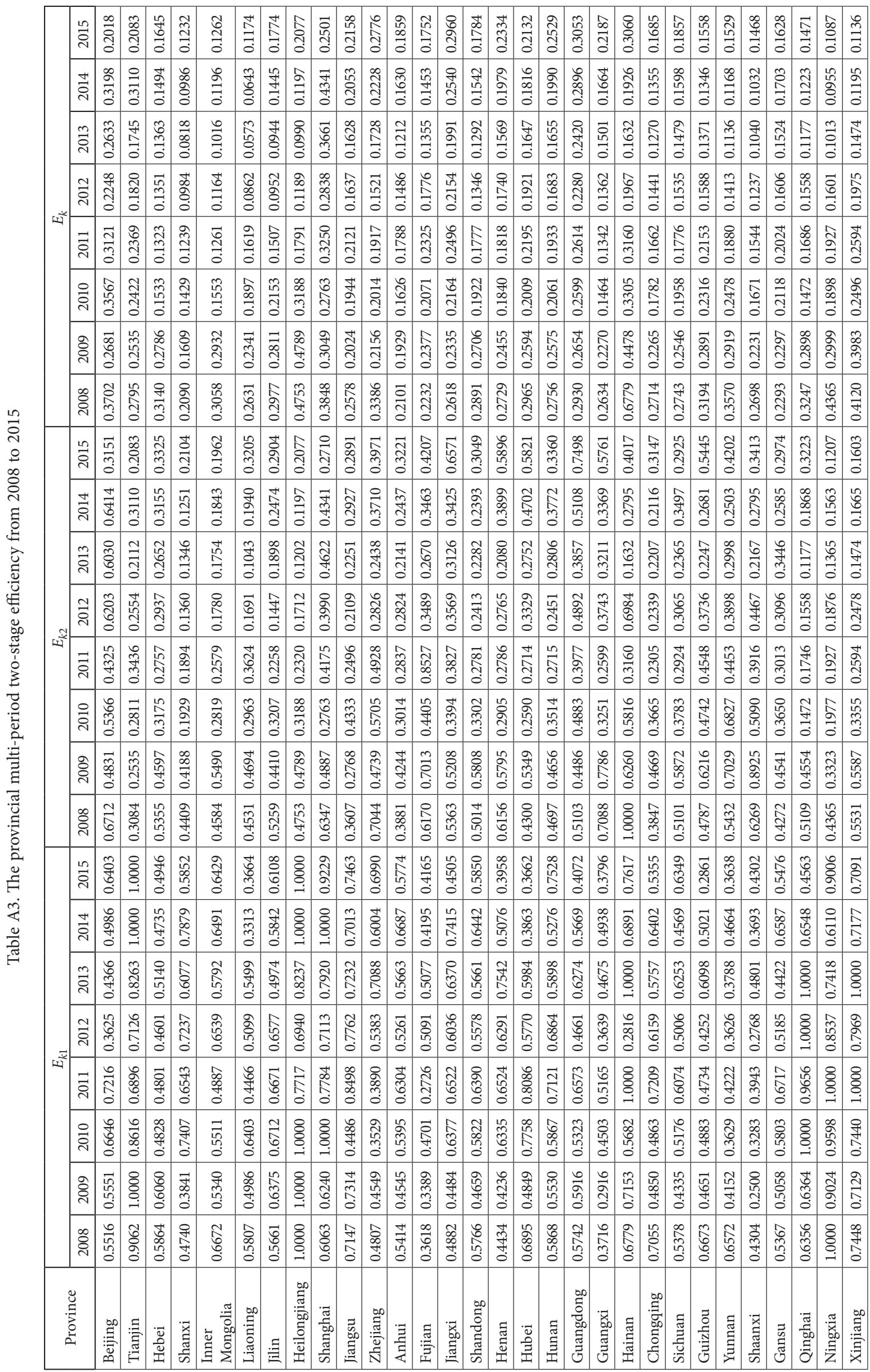




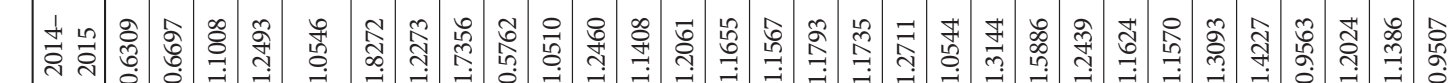

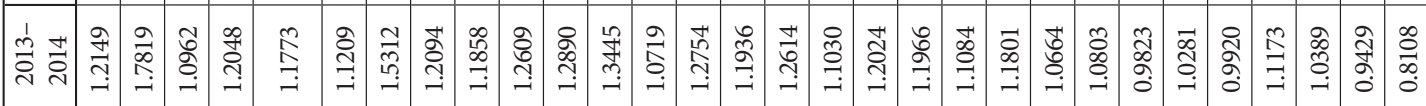

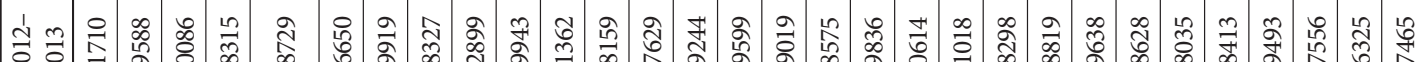

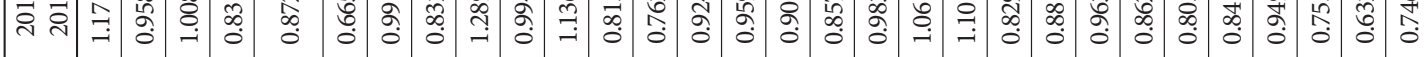

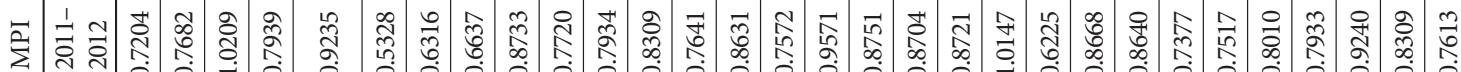

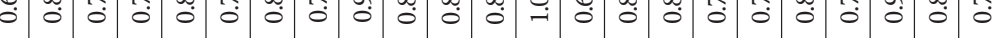

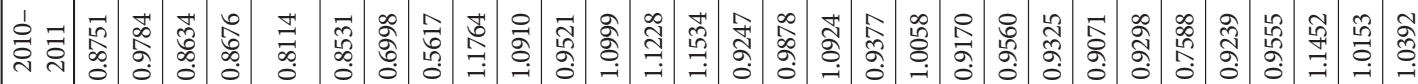

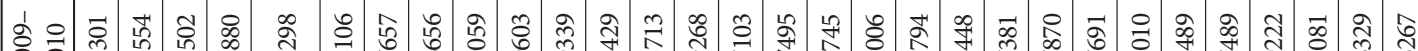

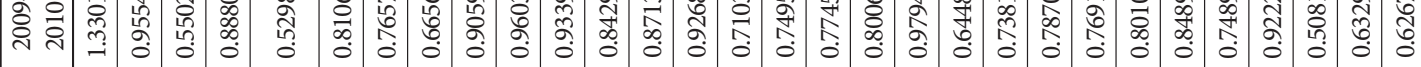

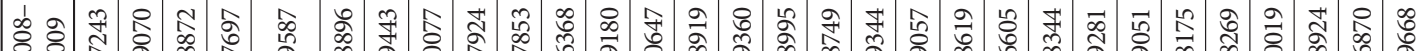

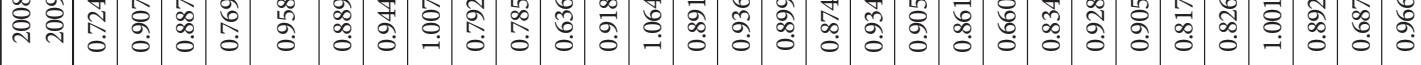

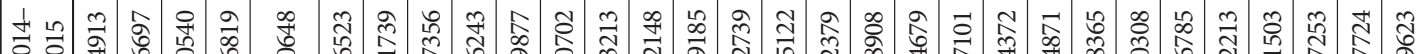

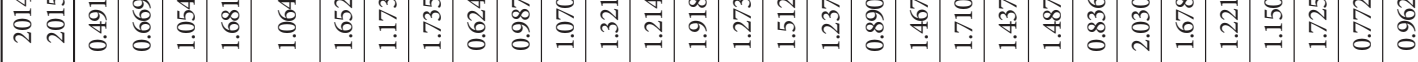

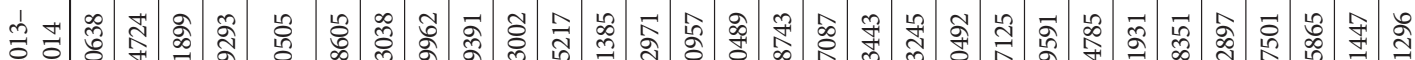

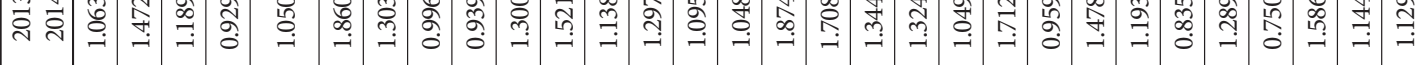

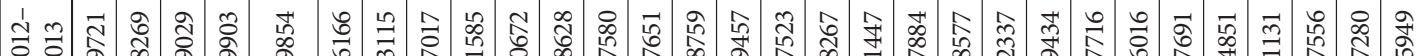

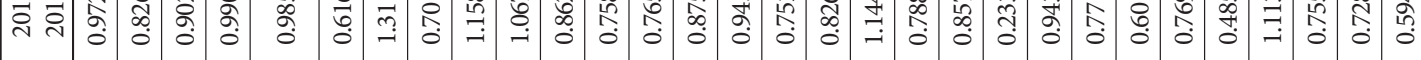

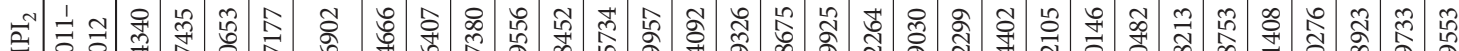

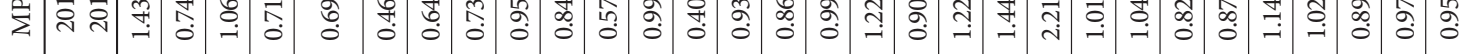

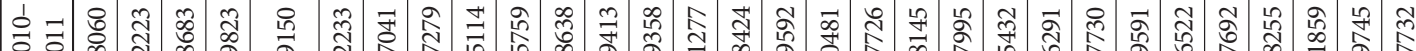

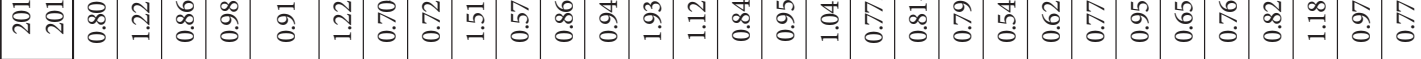

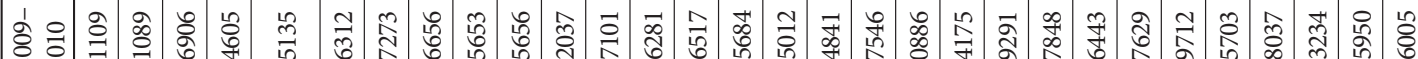



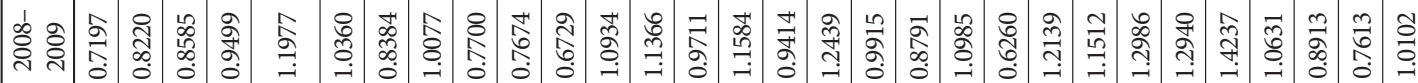

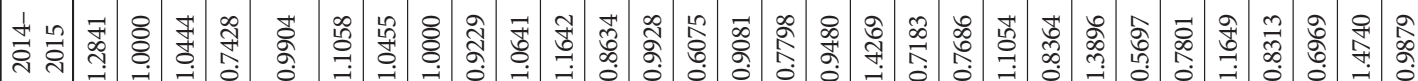

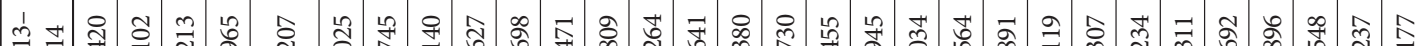

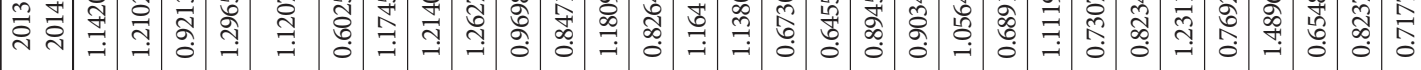

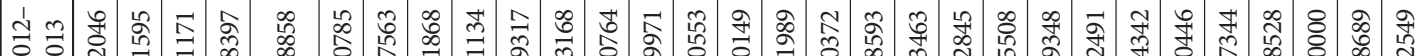

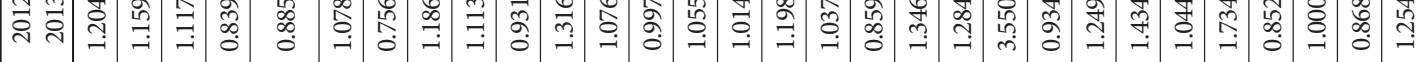

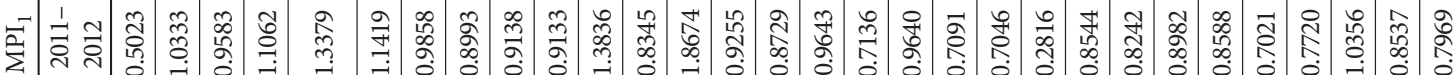

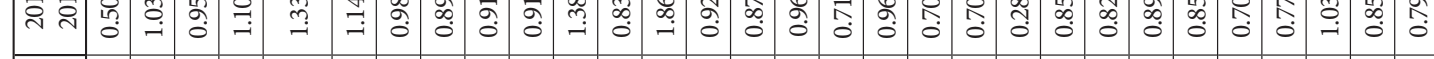

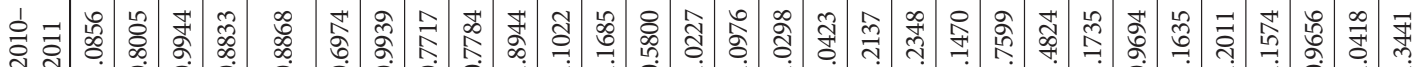



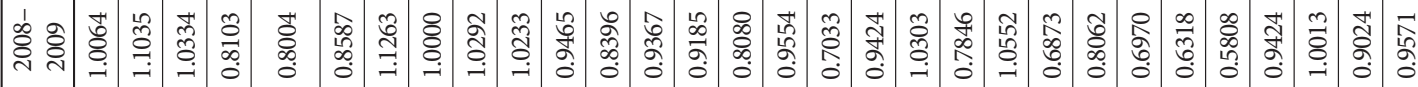
I 